\title{
Phytoplankton and littoral epilithic diatoms in high mountain lakes of the Adamello-Brenta Regional Park (Trentino, Italy) and their relation to trophic status and acidification risk
}

\author{
Monica TOLOTTI \\ Museo Tridentino di Scienze Naturali, Via Calepina 14, I-38100 Trento, Italy \\ Present Address: University of Innsbruck, Institute of Zoology and Limnology, Technikerstrasse 25, 6020 Innsbruck, Austria \\ e-mail: Monica.Tolotti@uibk.ac.at
}

\begin{abstract}
A survey of phytoplankton and littoral epilithic diatom communities was carried out on 16 high mountain lakes in the AdamelloBrenta Regional Park (NE Italy) as part of a wider research project aimed to the limnological characterisation of the seldom-studied lakes in this Alpine Region. The regional study was supplemented by the analysis of seasonal variations in two representative lakes. The principal goals of this paper are 1) to identify the most important environmental variables regulating patterns in the species composition of both phytoplankton and littoral diatoms, 2) to evaluate whether these algal communities can be used to improve trophic classification and 3) whether they can facilitate monitoring of diffuse human impacts (e.g. airborne pollution) on high altitude lakes. The relevance to monitoring is based on the acid sensitivity of all lakes studied, as indicated by the very low average alkalinity values (4-97 $\mu \mathrm{eq} \mathrm{l}^{-1}$ ) recorded during the investigation period. Chlorophyll-a concentrations and phytoplankton biovolume recorded in the lakes were very low, with maxima in the deep-water layers and in late summer. Phytoplankton communities were dominated by flagellated algae (Chrysophyceae and Dinophyceae). Several coccal green algae were present, while planktonic diatoms were almost completely absent. Littoral diatom communities were dominated by alpine and acidophilous taxa (mainly belonging to the genera Achnanthes and Eunotia). Trophic classification based on phytoplankton and littoral diatoms, respectively, ascribed all lakes to the oligotrophic range. In both algal communities species indicative of acidified conditions were found. Multivariate analyses indicated that both the regional distribution and seasonal variation of phytoplankton are mainly driven by nutrient concentration. Diatoms are predominantly affected by geochemical characteristics including $\mathrm{pH}$ and mineralization level.
\end{abstract}

Key words: high mountain lakes, phytoplankton, littoral epilithic diatoms, trophic status, acidification risk

\section{INTRODUCTION}

High mountain lakes have attracted the interest of limnologists for a long time, mainly because of their extreme climatic and physico-chemical conditions. Relatively recent research confirmed the presence of stable phytoplankton communities and presented evidence of primary productivity in these nutrient-poor environments (Rhode 1955). This stimulated further research, which strongly improved knowledge of the ecology of phytoplankton in high mountain lakes and highlighted a clear similarity between alpine and arctic lakes (e.g. Nauwerck 1966; Pechlaner 1971).

During the last two decades the study of phytoplankton dynamics in high mountain lakes has focussed on eutrophication processes (Heinonen 1980; Brettum 1989), acidification in Europe (e.g. Willén et al. 1990; Nauwerck 1994) and in America (e.g. Schindler et al. 1981) and climatic changes (e.g. Halac et al. 1997). Compared to phytoplankton, relatively little research has been undertaken on phytobenthonic communities of mountain and high mountain lakes (Rott \& Pernegger 1994). Similarly, relative to the numerous studies on diatoms from sediment cores (e.g. Arzet 1987; Marchetto \& Schmidt 1993), the investigation of littoral diatoms became more common only recently. This approach has been used to study biodiversity of epilithic communities of oligotrophic lakes (Lange-Bertalot \& Metzeltin 1996), eutrophication in low altitude lakes (Hofmann 1994), nutrient enrichment by airborne pollution and acidification processes in high mountain lakes (e.g. Niederhauser 1993).

Traditionally, phytoplankton and benthonic diatoms are analysed and discussed separately, with different relationships between these and the environmental variables assumed, due to their different ecology. The methods adopted for the analysis of the two algal communities are different, being based mainly on total biovolume for phytoplankton and on number of individuals for benthonic diatoms. However, recent investigations (Vinerbrooke \& Leavitt 1999) highlighted how an integrated approach to the analysis of algal communities could improve the understanding of the responses of freshwater algae to environmental variables. This approach appears to be particularly important for high mountain lakes because they are highly sensitive to environmental change, mainly due to extreme climatic conditions and low buffering capacity. Additionally, evidence shows that organic pollutants and diffuse airborne contaminants are common human impacts in several Alpine regions (Psenner \& Catalan 1994). 


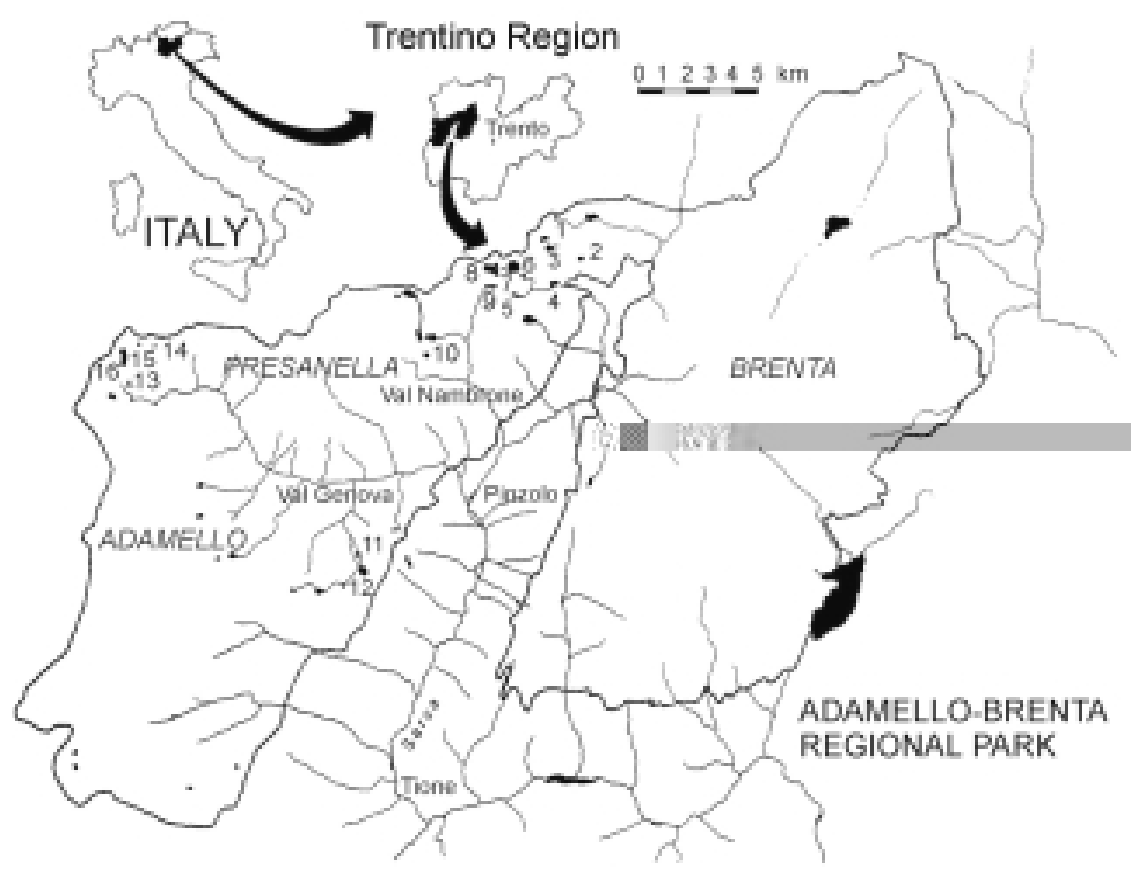

Fig. 1. Location of the lakes studied in the Adamello-Brenta Regional Park. 1 = Artuic (ARTU); 2 = Scuro delle Malghette (SMAL); $3=$ Tre Laghi (TREL); 4 = Ritorto (RITO); $5=$ Lambin (LAMB); $6=$ Serodoli (SERO); 7 = Serodoli Medio (SMED); $8=$ Gelato (GELA); 9 = Nambrone (NAMB); $10=$ Nero di Cornisello (NERO); $11=$ S. Giuliano (SGIU); $12=$ Garzoné $($ GARZ); $13=$ Mandrone (MAND); 14 = Rotondo (ROTO); 15 = Ghiacciato (GHIA); 16 = Scuro del Mandrone (SMAN).

Knowledge of algal communities in high altitude lakes of the Italian Alps is still incomplete, although limnological studies of alpine lakes go back to the beginning of last century (e.g. Stella 1931; Tonolli 1947). It is only during the last two decades that studies on phytoplankton of high mountain lakes in Italy have increased as a consequence of the threat of acid deposition over several regions in the Alps (e.g. Pugnetti \& Bettinetti 1995; Salmaso \& Decet 1997) and as a result of several research projects supported by the European Community.

As part of a project for the general limnological characterisation of alpine lakes in Trentino Region (NE Italy), a survey of phytoplankton and littoral diatoms communities was carried out on a group of high mountain lakes in the Adamello-Brenta Regional Park (Fig. 1) from 1996 to 1998, with the purpose of contributing to an understanding of biodiversity in this protected area. The principal aims of this survey were to identify the most important environmental variables regulating patterns in the species composition of phytoplankton and littoral diatoms and to evaluate the use of these algal communities both for the improvement of trophic classification and for monitoring of direct and diffuse human impacts.

\subsection{Site description}

The Adamello-Brenta Regional Park is a protected area of about $600 \mathrm{~km}^{2}$ in NE Italy (Fig. 1). It comprises two mountain ranges: the Adamello on crystalline rocks, as granites and tonalities, and the Brenta on sedimentary rocks. High mountain lakes are only found in the Adamello-Presanella mountain range in the Western part of the Park. Few specific studies of lakes in this district have been undertaken (e.g. Baldi 1932b; Zucchelli 1952). Most of the previous assessments have been made as part of general limnological investigations devoted to broader areas within the Italian Alps (Tonolli \& Tonolli 1951; Tomasi 1962; Giussani et al. 1986). For this reason the primary objective of this research project was to select a group of high mountain lakes for a detailed limnological study, based on a first screening and morphological assessment of the 59 lakes located within the Park. This paper describes an examination of 16 lakes situated on crystalline rocks in the Adamello-Presanella mountain ranges (Fig. 1) sampled for both phytoplankton and littoral diatoms.

The 16 lakes are located above the tree line (1936 $2663 \mathrm{~m}$ a.s.l., Tab. 2) in catchments comprising exposed rocks, gravel formations, grassland and shrub patches in different proportions according to altitude. The lakes are of glacial origin and have a median catchment area of $0.8 \mathrm{~km}^{2}$. No significant correlation between lake altitude and catchment area was found (Tolotti 2001, in press). Lake area ranges between 0.3 and 11.6 ha and lake depth varies between 3 and $33.7 \mathrm{~m}$. The largest and deepest lakes are dammed (Tab. 2) to increase lake volume for hydroelectric power generation. This type of exploitation was stopped in 1990 for all lakes but Lake Serodoli (Fig. 1), which is still occasionally used as 
drinking water supply during winter (Dori, pers. com.). Pasture and tourist activities are limited to the two lakes below $2000 \mathrm{~m}$ a.s.l., while illegal stocking by alloktonous fishes has been occasionally detected in several lakes (De Carli, pers. com.).

Tre Laghi (TREL) and Serodoli (SERO) were selected for a seasonal survey. They are located in adjacent valleys in the Presanella mountain range (Fig. 1) and are characterised by similar altitude (2257 and 2371 $\mathrm{m}$ a.s.l. respectively), aspect and exposure. Although only Lake SERO is dammed, TREL cannot be considered as completely undisturbed, as it is occasionally stocked with lake trout and American char.

\section{METHODS}

\subsection{Sampling}

The 16 lakes were sampled once during summer 1996 (end of June to the end of August). The lakes TREL and SERO were additionally sampled monthly during the ice-free period in 1997 (end of June to end of October), in late winter 1997/98 and in June 1998. Temperature, dissolved oxygen, $\mathrm{pH}$ and conductivity were measured at one meter intervals over a depth profile at the deepest point of the lakes, using a multiparametric Hydrolab probe. Water samples for the chemical analyses were taken with a Patalas-Schindler sampler at constant depths $(0-2.5-5$ and every $10 \mathrm{~m}$ down to the bottom). For each lake one to four subsamples, according to maximum lake depth and Secchi disc visibility were taken from the same bottles, for chlorophyll and phytoplankton analyses. For the seasonal study, samples for chlorophyll and phytoplankton were collected from the same depths at each sampling occasion $(0,5,10,14 \mathrm{~m}$ at Lake TREL and $0,5,10,15$, 20, $25 \mathrm{~m}$ at Lake SERO). The samples for chlorophyll analyses $(2-41)$ were filtered in the field and were stored at $-20{ }^{\circ} \mathrm{C}$ until the analysis. The samples for phytoplankton analyses (1 1 ) were preserved with acidic Lugol's solution.

Two different substrata were considered for the investigation of the littoral diatom communities: stones (obtained by brushing several stones collected from at least $50 \mathrm{~cm}$ depth at different places along the lake shore) and debris (obtained by removing the upper layer of soft sediment along the shore). Samples were fixed with formalin at the final concentration of $4 \%$.

\subsection{Laboratory analysis}

Chemical analyses, including $\mathrm{pH}$, alkalinity, conductivity, major ions and nutrient concentrations, were carried out following I.R.S.A.-C.N.R. (1994). Alkalinity was determined using potentiometric endpoint titration. Ammonia-nitrogen and nitrate-nitrogen were measured by spectrophotometry after reaction with sodium salicilate and sodium salicilate Seignette salt, respectively. Soluble reactive phosphorus (SRP) was determined by spectrophotometry using the ascorbic acid method and total phosphorus (TP) using the same method after potassium persulphate digestion. Sulphates were analysed by turbidometry and ionic chromatography and silica by spectrophotometry.

Chlorophyll- $a$ concentrations were determined by spectrophotometry after extraction in 90\% acetone (Lorenzen 1967). Correction for phaeophytine a was carried out using $\mathrm{HCl}$ at the final concentration of 3.10$3 \mathrm{~N}$ (Marker et al. 1980). Hereafter, total chlorophyll concentrations is defined as the sum of chlorophyll and phaeophytine- $a$.

Phytoplankton samples (1 1$)$ were pre-concentrated to a final volume of $250 \mathrm{ml}(4: 1)$ by sedimentation in glass cylinders for 7-10 days. Counts were carried out according to Utermöhl (1958) after sedimentation in glass chambers. At each magnification, at least 100 individuals of the most frequent taxa were counted, corresponding to a maximum statistical error of $20 \%$ (Lund et al. 1958). The biovolumes of the different taxa were calculated approximating the cell shape to simple geometrical solids (Rott 1981).

Diatoms were cleaned by boiling the samples in $35 \%$ hydrogen peroxide. Oxidation of organic matter was completed adding small amounts of $\mathrm{K}_{2} \mathrm{CrO}_{7}$ (Schiefele \& Kohmann 1993). The cleaned valves were embedded in Naphrax resin, with a refractive index of 1.7. The mounts are stored in the collection of the Museo Tridentino di Scienze Naturali of Trento, Italy (MTSN). The samples from stones were counted at 1000-times magnification in bright field (at least 400 valves), while debris samples were used to complete the species list of each lake.

\subsection{Data analysis}

The trophic classification of the lakes was performed using several methods using different parameters, with the aim of improving the ranking of the relatively homogeneous lakes studied. In addition to the OECD method, based on TP and chlorophyll- $a$ concentrations (Vollenweider \& Kerekes 1982), four methods based on phytoplankton biovolume (Vollenweider 1968; Heinonen 1980; Rott 1984; Brettum 1989) and the Hofmann's method (1994), based on littoral diatoms (Tab. 1), were used. The choice of an approach based on phytoplankton is underpinned by the absence of a specific classification system for high mountain lakes in the Alps and because it is possible to check the applicability of different methods for the trophic classification of the category of lakes studied. The methods were mainly selected according to morphological and geographical criteria: Heinonen and Brettum's methods were calibrated on Scandinavian lakes, Rott's method on forested mountain lakes in Tyrol (Austria).

Species diversity of both phytoplankton and littoral diatom samples was calculated using the Shannon-Wiener Index (2 based logarithms, Shannon \& Weaver 1949). 
Tab. 1. Methods used for the trophic classification of the lakes studied.

\begin{tabular}{|c|c|c|c|c|c|}
\hline Author & Variable & $\begin{array}{l}\text { ULTRAOLIGO- } \\
\text { TROPHIC }\end{array}$ & $\begin{array}{l}\text { OLIGO- } \\
\text { TROPHIC }\end{array}$ & $\begin{array}{l}\text { OLIGOMESO- } \\
\text { TROPHIC }\end{array}$ & $\begin{array}{l}\text { MESO- } \\
\text { TROPHIC }\end{array}$ \\
\hline Vollenweider (1968) & $\begin{array}{c}\text { Phytopl. biovol. }\left(\mathrm{mm}^{3} \mathrm{~m}^{-3}\right) \text { annual } \\
\text { maximum }\end{array}$ & $<1000$ & $1000-3000$ & --- & $3001-5000$ \\
\hline Heinonen (1980) & $\begin{array}{l}\text { Phytopl. biovol. }\left(\mathrm{mm}^{3} \mathrm{~m}^{-3}\right) \text { mid- } \\
\text { summer value }\end{array}$ & $<200$ & $200-500$ & $501-1000$ & $1001-2500$ \\
\hline Rott (1984) & $\begin{array}{c}\text { Phytopl. biovol. }\left(\mathrm{mm}^{3} \mathrm{~m}^{-3}\right) \text { annual } \\
\text { average }\end{array}$ & --- & $<500$ & --- & $500-2000$ \\
\hline \multirow[t]{2}{*}{ Brettum (1989) } & $\begin{array}{c}\text { Phytopl. biovol. }\left(\mathrm{mm}^{3} \mathrm{~m}^{-3}\right) \text { annual } \\
\text { maximum }\end{array}$ & $<200$ & $200-700$ & $701-1200$ & $1201-3000$ \\
\hline & $\begin{array}{c}\text { Phytopl. Biovol. }\left(\mathrm{mm}^{3} \mathrm{l}^{-1}\right) \text { vegetation } \\
\text { period average }\end{array}$ & $<120$ & $120-400$ & $401-600$ & $601-1500$ \\
\hline Vollenweider \& Kerekes & Chl- $a\left(\mu \mathrm{g} \mathrm{l}^{-1}\right)$ annual maximum & $<2.5$ & $<8$ & --- & $8-25$ \\
\hline \multirow[t]{2}{*}{ (1982) } & Chl- $a\left(\mu \mathrm{g} \mathrm{l}^{-1}\right)$ annual average & $<1$ & $<2.5$ & --- & $2.5-8$ \\
\hline & $\mathrm{TP}\left(\mu \mathrm{g} \mathrm{l}^{-1}\right)$ annual average & $<4$ & $<10$ & --- & $10-35$ \\
\hline Hofmann (1994) & Littoral diatom INDEX & --- & $1.00-1.99$ & $2.00-2.49$ & $2.50-3.49$ \\
\hline
\end{tabular}

The numerical analyses were carried out separately for phytoplankton and littoral benthonic diatoms, thus allowing for the different ecology of the two communities and the different methodological approaches commonly adopted. Nevertheless, the results of the two analyses were combined and evaluated together to allow a comparison of responses of phytoplankton and littoral diatoms to the driving environmental variables to be made and to assess the two algal communities as potential indicators of human impacts on mountain lakes. In this paper the results of the analyses of the two communities are evaluated in a hierarchical way, linking the littoral diatom (Tolotti 2001, in press) to the phytoplankton results. The reason for this approach stems from the availability of a larger phytoplankton data set, relative to the diatom data. More phytoplankton samples were generated from the depth profiles and from different sampling periods and therefore it was possible to directly link the phytoplankton data to the temporal variation of the physico-chemical parameters measured along the water column.

The TWINSPAN program (Hill et al. 1975) was used for the classification of samples based on their phytoplankton species composition. TWINSPAN analyses were restricted to species with average relative abundances $\geq 0.5 \%$. Redundancy analysis (CANOCO, Ter Braak 1988) was used for the combined evaluation of phytoplankton assemblages and environmental variables. Depth weighted averages of relative abundances of phytoplankton taxa (in terms of biovolume) and physico-chemical variables (Tabs 2 and 3) were used. Environmental variables showing high correlations with others (e.g. conductivity or SRP), were excluded after a first run using CANOCO. The significance of the eigenvalues was tested by Monte Carlo permutation module (199 permutations) for the first canonical axis and for the sum of all four canonical axes. Seasonal variations in TREL and SERO were evaluated by classifying each singular phytoplankton sample. In this case redundancy analysis (RDA) performed better when re- stricted to species with average relative abundances $\geq 0.5 \%$ in at least three samples.

\section{RESULTS}

\subsection{Environmental variables}

Discussion of the chemistry of the study lakes here relates to depth-weighted averages (Tabs 2 and 3). The values of the most important chemical parameters are, for the most part, distributed uniformly down the water column. Only water temperature and oxygen saturation exhibited variations relative to lake depth and sampling date. The majority of lakes sampled in early summer 1996 showed regularly decreasing temperatures down to the bottom or a slight stratification in the upper layers ( $\mathrm{G}$ and B in Tab. 2 respectively). Only three deep lakes, sampled in mid summer, exhibited a clear metalimnion ( $\mathrm{S}$ in Tab. 2) with low oxygen saturations in the deepest water layers (minimum $=10 \%$ in Lake NERO at $30 \mathrm{~m}$ depth). Lakes TREL and SERO exhibited the typical temperature pattern of dimictic, holomictic lakes. Both lakes were characterised by homeothermic conditions in June and October 1997 and were clearly stratified from July to the end of September (Tolotti \& Cantonati 2000). As a consequence of the prolonged summer and winter stratification, particularly low oxygen saturation values were recorded in both lakes in late summer and late winter (Tab. 3).

All lakes are characterised by a very low mineralization level and are weakly buffered due to the lithology of the Adamello-Presanella mountain ranges. Average conductivity ranges between 8 and $21 \mu \mathrm{S} \mathrm{cm}^{-1}$. $\mathrm{pH}(5.7$ 6.7) and alkalinity (4-97 $\mu$ eq $1^{-1}$, Tab. 2 ) values indicate that the lakes are acid sensitive (Tolotti \& Cantonati 2000). The highest conductivity and alkalinity values were recorded in the two lakes below $2000 \mathrm{~m}$ a.s.1. Major ion concentrations were low and uniform (Tolotti 2001, in press). Only sulphate (Tab. 2) and other ions correlated to alkalinity (e.g. $\mathrm{Ca}$ and $\mathrm{Cl}$ ) exhibited a slightly wider range $\left(0.8-2.3 \mathrm{mg} \mathrm{l}^{-1}\right.$ and $0.2-1.8 \mathrm{mg}$ $1^{-1}$, respectively). Nutrient concentrations were particu- 
Tab. 2. Important morphological, physico-chemical (used for the numerical analyses) and biological parameters of the 16 lakes studied in summer 1996. Averages are intended over the depth profile. Lake numbers and codes as in figure 1 . $\mathrm{G}=\mathrm{dec}$.easing gradient; $\mathrm{B}=$ beginning; $\mathrm{S}=$ stratified; $\mathrm{z}_{\max }=$ maximum depth; $\mathrm{U}=$ ultraoligotrophic; $\mathrm{O}=$ oligo-trophic; $\mathrm{OM}=$ oligomesotrophic; $\mathrm{M}=$ mesotrophic. $*$ = relative to the debris sample only.

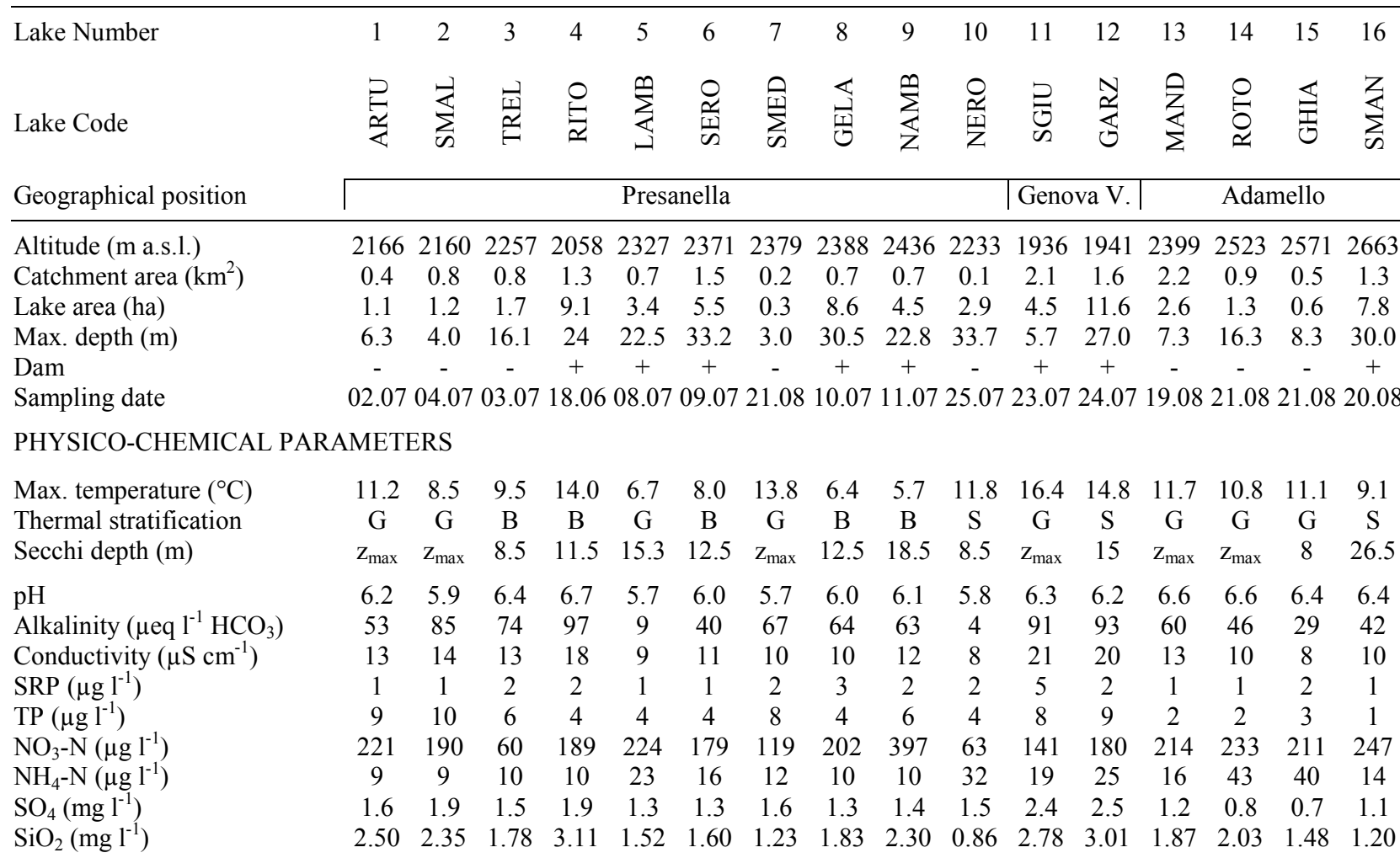

\section{BIOLOGICAL PARAMETERS}

\section{PHYTOPLANKTON}

\begin{tabular}{lcccccccccccccccc} 
Max. Chl- $a\left(\mu \mathrm{g}^{-1}\right)$ & 0.7 & 0.6 & 1.0 & 1.5 & 1.7 & 1.8 & 0.7 & 1.1 & 0.9 & 6.8 & 1.7 & 4.6 & 0.5 & 0.5 & 0.9 & 0.4 \\
Depth of max. Chl- $a(\mathrm{~m})$ & 1 & 2.5 & 5 & 12 & 10 & 10 & 2.5 & 10 & 10 & 15 & 4.5 & 20 & 5 & 5 & 5 & 25 \\
Average Chl- $a\left(\mu \mathrm{g} \mathrm{l}^{-1}\right)$ & 0.6 & 0.6 & 0.9 & 1.3 & 1.0 & 1.0 & 0.7 & 1.1 & 0.7 & 4.2 & 1.7 & 3.4 & 0.5 & 0.4 & 0.9 & 0.3 \\
N. phytopl. taxa identified & 35 & 24 & 39 & 39 & 32 & 35 & 19 & 27 & 20 & 34 & 26 & 33 & 21 & 16 & 8 & 12 \\
Max. phyto. biovol. $\left(\mathrm{mm}^{3} \mathrm{~m}^{-3}\right)$ & 63 & 24 & 20 & 533 & 39 & 14 & 19 & 68 & 17 & 513 & 424 & 489 & 23 & 28 & 68 & 67 \\
Depth of max. biovolume $(\mathrm{m})$ & 1 & 2.5 & 2.5 & 12 & 10 & 10 & 2.5 & 10 & 10 & 15 & 4.5 & 10 & 5 & 10 & 5 & 25 \\
Aver. phyto. biovol. $\left(\mathrm{mm}^{3} \mathrm{~m}^{-3}\right)$ & 47 & 24 & 19 & 199 & 21 & 13 & 19 & 43 & 25 & 334 & 424 & 308 & 17 & 14 & 68 & 46 \\
Shannon-Wiener Index & 2.2 & 2.1 & 3.5 & 2.5 & 3.8 & 3.0 & 2.1 & 2.7 & 2.3 & 2.9 & 2.6 & 1.1 & 2.3 & 2.1 & 0.2 & 0.5 \\
Trophic level & & & & & & & & & & & & & & & \\
OECD-aver. TP & $\mathrm{O}$ & $\mathrm{M}$ & $\mathrm{O}$ & $\mathrm{O}$ & $\mathrm{O}$ & $\mathrm{O}$ & $\mathrm{O}$ & $\mathrm{O}$ & $\mathrm{O}$ & $\mathrm{O}$ & $\mathrm{O}$ & $\mathrm{O}$ & $\mathrm{U}$ & $\mathrm{U}$ & $\mathrm{U}$ & $\mathrm{U}$ \\
OECD-aver. Chl- $a$ & $\mathrm{U}$ & $\mathrm{U}$ & $\mathrm{U}$ & $\mathrm{O}$ & $\mathrm{U}$ & $\mathrm{O}$ & $\mathrm{U}$ & $\mathrm{O}$ & $\mathrm{U}$ & $\mathrm{M}$ & $\mathrm{O}$ & $\mathrm{M}$ & $\mathrm{U}$ & $\mathrm{U}$ & $\mathrm{U}$ & $\mathrm{U}$ \\
Heinonen $(1980)-$ midsummer & $\mathrm{U}$ & $\mathrm{U}$ & $\mathrm{U}$ & $\mathrm{U}$ & $\mathrm{U}$ & $\mathrm{U}$ & $\mathrm{U}$ & $\mathrm{U}$ & $\mathrm{U}$ & $\mathrm{O}$ & $\mathrm{O}$ & $\mathrm{O}$ & $\mathrm{U}$ & $\mathrm{U}$ & $\mathrm{U}$ & $\mathrm{U}$ \\
Total N. diatom taxa identified & 99 & 89 & 122 & 56 & 52 & 80 & 84 & 61 & $35 *$ & 43 & 55 & 75 & 71 & 77 & 63 & 47 \\
Shannon-Wiener Index & 4.9 & 4.5 & 4.2 & 2.2 & 3.7 & 3.3 & 5.0 & 4.8 & --- & 3.4 & 1.7 & 2.8 & 3.8 & 4.6 & 3.8 & 3.3 \\
Trophic Index (Hofmann & 1.68 & 1.56 & 1.83 & 1.79 & 1.51 & 1.64 & 1.67 & 1.59 & --- & 1.50 & 1.69 & 2.09 & 1.76 & 1.59 & 1.55 & 1.58 \\
1994) & & & & & & & & & & & & & \\
\hline
\end{tabular}

larly low in all the lakes investigated. The median SRP value was approximately $2 \mu \mathrm{g} \mathrm{l}^{-1}$, with a minimum of $0.8 \mu \mathrm{g} \mathrm{l}^{-1}$ recorded in Lake LAMB. TP, even with a low median value (about $6 \mu \mathrm{g} \mathrm{l}^{-1}$ ) exhibited a slightly wider range (ca $1-10 \mu \mathrm{g} \mathrm{l}^{-1}$, Tab. 2). According to average TP concentrations, 4 of the lakes studied can by classed as ultraoligotrophic and 12 as oligotrophic (OECD, Vollenweider \& Kerekes 1982). Silica concentrations var- ied between $1.5 \mathrm{mg} \mathrm{l}^{-1}$ to $3.1 \mathrm{mg} \mathrm{l}^{-1}$. Nitrogen was the chemical parameter with the largest variability. $\mathrm{NO}_{3}-\mathrm{N}$ ranged from about $60 \mu \mathrm{g} \mathrm{l}^{-1}$ (lakes TREL and NERO) to about $400 \mu \mathrm{g} \mathrm{l}^{-1}$ (NAMB), while $\mathrm{NH}_{4}-\mathrm{N}$ ranged from 9 to $43 \mu \mathrm{g} \mathrm{l^{-1 }}$.

The two lakes studied for the seasonal survey showed comparable mineralization levels, with somewhat lower values in Lake SERO (Tab. 3). Pronounced 
Tab. 3. Important physico-chemical (used for the numerical analyses) and biological parameters of lakes Tre Laghi (TREL) and Serodoli (SERO). Averages are intended over the depth profile. J7 = June 97; J = July 97; A = August 97; $\mathrm{S}=$ September 97; O = October 97; $\mathrm{F}=$ February 98; $\mathrm{M}=$ March 98; J8 = June 98; $\mathrm{A}=$ absent; $\mathrm{B}=$ beginning; $\mathrm{S}=$ stratified; $\mathrm{H}=$ homeothermic; IS = inversely stratified; $\mathrm{U}=$ ultraoligotrophic; $\mathrm{O}=$ oligotrophic; $\mathrm{OM}=$ oligomesotrophic; $\mathrm{M}=$ mesotrophic; $\mathrm{E}=$ eutrophic; $*=$ relative to the stone samples only.

\begin{tabular}{|c|c|c|c|c|c|c|c|c|c|c|c|c|c|c|c|c|}
\hline \multirow{3}{*}{$\begin{array}{l}\text { Lake Code } \\
\text { Sampling month }\end{array}$} & \multicolumn{8}{|c|}{ TREL } & \multicolumn{8}{|c|}{ SERO } \\
\hline & $\mathrm{J} 7$ & $\mathrm{~J}$ & A & $\mathrm{S}$ & $\mathrm{O}$ & F & J8 & Aver. & J7 & $\mathrm{J}$ & A & $\mathrm{S}$ & $\mathrm{O}$ & M & J8 & Aver \\
\hline & 20 & 18 & 20 & 25 & 29 & 26 & 10 & & 19 & 19 & 21 & 26 & 30 & 12 & 29 & \\
\hline \multicolumn{17}{|c|}{ PHYSICO-CHEMICAL PARAMETERS } \\
\hline Max. temperature $\left({ }^{\circ} \mathrm{C}\right)$ & 7.8 & 12.4 & 13.3 & 14.5 & 6.2 & 4.0 & 4.1 & 8.9 & 4.6 & 9.9 & 12.3 & 11.2 & 6.4 & 4.0 & 7.4 & 8.0 \\
\hline Thermal stratificat & $\mathrm{B}$ & $\mathrm{S}$ & $\mathrm{S}$ & $\mathrm{S}$ & $\mathrm{H}$ & IS & $\mathrm{H}$ & & $\mathrm{H}$ & $\mathrm{S}$ & $\mathrm{S}$ & $\mathrm{S}$ & $\mathrm{H}$ & IS & $\mathrm{B}$ & \\
\hline Secchi depth (m) & 12.3 & --- & 10.5 & 7.2 & 5.5 & --- & 13.0 & 9.7 & --- & 14.8 & 18.7 & 23.5 & 18.0 & --- & 18.0 & 18.6 \\
\hline $\mathrm{pH}$ & 5.9 & 5.9 & 6.2 & 6.2 & 6.5 & 6.2 & 5.9 & 6.1 & 5.4 & 5.7 & 5.9 & 5.9 & 6.1 & 5.8 & 5.9 & 5.8 \\
\hline Alkalinity $\left(\mu \mathrm{eq} \mathrm{l}^{-1} \mathrm{HCO}_{3}\right)$ & 63 & --- & 77 & 70 & 90 & 135 & 63 & 83 & 43 & --- & 65 & 38 & 47 & 43 & 51 & 48 \\
\hline Conductivity $\left(\mu \mathrm{S} \mathrm{cm}^{-1}\right)$ & 13 & 12 & 12 & 14 & 15 & 17 & 13 & 14 & 12 & 11 & 10 & 11 & 11 & 11 & 10 & 11 \\
\hline $\operatorname{SRP}\left(\mu \mathrm{g} \mathrm{l}^{-1}\right)$ & 1 & 1 & 2 & 2 & 1 & 2 & 1 & 1 & 4 & 1 & 2 & 1 & 1 & 1 & 2 & 2 \\
\hline $\mathrm{TP}\left(\mu \mathrm{g}^{-1}\right)$ & 8 & 5 & 7 & 7 & 5 & 6 & 5 & 6 & 7 & 3 & 6 & 4 & 4 & 4 & 5 & 5 \\
\hline $\mathrm{NO}_{3}-\mathrm{N}\left(\mu \mathrm{l}^{-1}\right)$ & 146 & 121 & 74 & 59 & 43 & 116 & 126 & 98 & 205 & 175 & 153 & 149 & 139 & 172 & 197 & 170 \\
\hline $\mathrm{NH}_{4}-\mathrm{N}\left(\mu \mathrm{l}^{-1}\right)$ & 50 & 13 & 12 & 8 & 7 & 18 & 26 & 19 & 44 & 22 & 12 & 9 & 10 & 20 & 36 & 22 \\
\hline $\mathrm{SO}_{4}\left(\mathrm{mg} \mathrm{l}^{-1}\right)$ & 1.6 & 1.4 & 1.7 & 1.5 & 1.8 & 1.8 & --- & 1.6 & 1.6 & 1.4 & 1.7 & 1.4 & 1.6 & 1.7 & 1.7 & 1.6 \\
\hline $\mathrm{SiO}_{2}\left(\mathrm{mg} \mathrm{l}^{-1}\right)$ & 2.18 & 2.01 & 2.16 & 2.05 & 2.37 & 1.99 & 2.10 & 2.12 & 1.87 & 1.85 & 1.84 & 1.71 & 1.87 & 2.13 & 1.78 & 1.86 \\
\hline
\end{tabular}

\section{BIOLOGICAL PARAMETERS}

\section{PHYTOPLANKTON}

\begin{tabular}{|c|c|c|c|c|c|c|c|c|c|c|c|c|c|c|c|c|}
\hline Max. chlorophyll- $a\left(\mu \mathrm{g}^{-1}\right)$ & 3.2 & 3.8 & 7.3 & 8.7 & 11.2 & 4.7 & 4.3 & 6.2 & 1.1 & 2.0 & 1.5 & 1.5 & 2.7 & 1.3 & 1.5 & 1.7 \\
\hline Depth of max. Chl- $a(\mathrm{~m})$ & 12.5 & 14 & 14 & 10 & 5 & 5 & 10 & 10.1 & 22.5 & 5 & 20 & 25 & 0 & 2.5 & 25 & 14.3 \\
\hline Average Chl- $a\left(\mu \mathrm{g} \mathrm{l}^{-1}\right)$ & 1.6 & 1.9 & 3.1 & 4.3 & 7.8 & 3.9 & 1.5 & 3.4 & 1.5 & 1.3 & 1.4 & 2.0 & 1.5 & 1.1 & 1.3 & 1.5 \\
\hline N. phytopl. taxa identified & 67 & 59 & 67 & 46 & 48 & 29 & 34 & 50.0 & 37 & 37 & 33 & 27 & 28 & 30 & 33 & 32 \\
\hline Max. phyto. biovol. $\left(\mathrm{mm}^{3} \mathrm{~m}^{-3}\right)$ & 955 & 226 & 319 & 1105 & 1509 & 391 & 1514 & 860 & 79 & 58 & 75 & 31 & 25 & 35 & 173 & 68 \\
\hline Depth of max. biovol. (m) & 12.5 & 14.0 & 14.0 & 14.0 & 5.0 & 2.5 & 14.0 & 10.9 & 22.5 & 15.0 & 15.0 & 25.0 & 0.0 & 0.0 & 25.0 & 14.6 \\
\hline Aver. phyto. biovol. $\left(\mathrm{mm}^{3} \mathrm{~m}^{-3}\right)$ & 382 & 134 & 240 & 637 & 1141 & 312 & 552 & 486 & 42 & 29 & 32 & 10 & 16 & 21 & 106 & 37 \\
\hline $\begin{array}{l}\text { Shannon-Wiener Index } \\
\text { Trophic level }\end{array}$ & 3.1 & 3.1 & 1.8 & 1.0 & 0.6 & 2.0 & 2.2 & 2.0 & 3.1 & 3.3 & 2.4 & 2.4 & 2.0 & 2.1 & 3.1 & 2.6 \\
\hline OECD-aver. TP & & & & & & & & $\mathrm{O}$ & & & & & & & & $\mathrm{O}$ \\
\hline OECD-aver. Chl- $a$ & & & & & & & & M & & & & & & & & $\mathrm{O}$ \\
\hline Vollenweider (1968) - max. & & & & & $\mathrm{O}$ & & & & & & & & & & $\mathrm{U}$ & \\
\hline Heinonen (1980) - midsummer & & & $\mathrm{O}$ & & & & & & & & $\mathrm{U}$ & & & & & \\
\hline Brettum (1988) - max. & & & & & $\mathrm{OM}$ & & & & & & & & & & $\mathrm{U}$ & \\
\hline Brettum (1988) - aver. & & & & & & & & $\mathrm{OM}$ & & & & & & & & $\mathrm{U}$ \\
\hline Rott (1984) - aver. & & & & & & & & $\mathrm{O}$ & & & & & & & & $\mathrm{O}$ \\
\hline \multicolumn{17}{|l|}{ LITTORAL DIATOMS } \\
\hline Total N. diatom taxa identified & --- & 83 & $48 *$ & 75 & 79 & --- & 104 & 85 & --- & 62 & 62 & 56 & $42 *$ & --- & 61 & 60 \\
\hline Shannon-Wiener Index & --- & 4.1 & 4.0 & 4.1 & 4.2 & --- & 4.3 & 4.1 & --- & 3.6 & 3.5 & 4.2 & 3.9 & --- & 3.8 & 3.8 \\
\hline $\begin{array}{l}\text { Trophic Index (Hofmann } \\
\text { 1994) }\end{array}$ & --- & 1.86 & 1.81 & 1.82 & 1.72 & --- & 2.04 & 1.85 & --- & 1.57 & 1.53 & 1.58 & 1.56 & --- & 1.58 & 1.56 \\
\hline
\end{tabular}

differences for alkalinity were noted, with TREL characterised by higher average values and clearer seasonal variations. The lowest alkalinity values were recorded in both lakes in June 1997 and 1998, a phenomenon recorded in several high mountain lakes in early summer as a consequence of the dilution processes during the snow melting (Thies et al. 2000). Average $\mathrm{pH}$ values were lower in Lake SERO than in TREL (5.8 and 6.1, respectively), but seasonal variations were similar in the two lakes, with a clear increase from early summer to autumn (Tab. 3). However, only Lake TREL exhibited similar seasonal patterns for alkalinity and $\mathrm{pH}$. SRP, TP and silica concentrations were similar in the two lakes and showed slight seasonal variations (Tab. 3). Both lakes were classed within the oligotrophic category (OECD, Vollenweider \& Kerekes 1982) according to their average TP concentrations. In spite of higher nitrate concentrations in TREL (Tab. 3), similar seasonal patterns of this nutrient were recorded in the two lakes, with maximum values in June and a progressive decrease through the summer.

\subsection{Chlorophyll-a, phytoplankton biovolume and trophic level}

Very low chlorophyll- $a$ concentrations were found in the majority of the lakes studied in the regional sur- 
vey (median $0.8 \mu \mathrm{g} \mathrm{l}^{-1}$ ). The highest values (up to $6.8 \mu \mathrm{g}$ $\left.1^{-1}\right)$ were recorded in two deep lakes sampled at the end of July, while the lowest concentrations were found in lakes sampled at the beginning of July and in the lakes of the Adamello mountain range (Tab. 2). The vertical distribution of chlorophyll showed different patterns according to water transparency and thermal stratification (Tolotti \& Cantonati 2000). In the deep and stratified lakes concentrations increased down to the deepest layers, as is typical for very transparent high mountain lakes (Pechlaner 1971; Tilzer 1972). Similar vertical distributions of chlorophyll were found in both the lakes studied in 1997 and 1998 during summer, while during the autumnal mixing period (October 1997) the values were uniformly distributed down the water column. In late winter, higher chlorophyll concentrations were recorded in the upper $5 \mathrm{~m}$ under the ice cover (Tolotti \& Cantonati 2000). However, despite similar vertical distributions, average chlorophyll concentration calculated for the whole sampling period was approximately twice as high in Lake TREL than in SERO (Tab. 3). In TREL the lowest values occurred in early summer, the highest concentrations being found in October $\left(11.2 \mu \mathrm{g} \mathrm{l^{-1 }}\right.$ at 5 $\mathrm{m})$ after a progressive increase during summer. This pattern appeared to be significantly $(\mathrm{p}<0.01)$ inversely correlated to seasonal variations of in $\mathrm{NO}_{3}-\mathrm{N}$ (Tolotti \& Cantonati 2000, Tab. 3). The chlorophyll concentration in Lake SERO remained fairly uniform during the whole ice-free period and did not show significant relations with any chemical parameter.

Average phytoplankton biovolume calculated for the lakes sampled during summer 1996 were very low (13 $424 \mathrm{~mm}^{3} \mathrm{~m}^{-3}$, Tab. 2), comparable with values recorded in high mountain lakes on acid rocks in the Alps (e.g. Schneider 1981; Pfister 1988; Pugnetti \& Bettinetti 1995) and in Swedish Lapland (e.g. Nauwerck 1994). Phytoplankton biovolume was significantly correlated ( $p<0.01$ ) with conductivity and TP (positively), and with altitude and $\mathrm{NO}_{3}-\mathrm{N}$ (negatively). The differences between lakes TREL and SERO, already highlighted by chlorophyll concentrations, were also reflected by the phytoplankton biovolume (Tab. 3), which showed a median value of $300 \mathrm{~mm}^{3} \mathrm{~m}^{-3}\left(32-1514 \mathrm{~mm}^{3} \mathrm{~m}^{-3}\right)$ in Lake TREL an order of magnitude greater than in Lake SERO $\left(25 \mathrm{~mm}^{3} \mathrm{~m}^{-3}\right.$, range $\left.4-173 \mathrm{~mm}^{3} \mathrm{~m}^{-3}\right)$. In Lake TREL the highest phytoplankton biovolume was recorded in October while the lowest occurred in late winter and late spring (June 1998, Tab. 3). In Lake SERO the highest values occurred in June 1998 and the lowest values were observed in autumn and winter (Tab. 3). In TREL the biovolume exhibited a significant ( $p$ $<0.01)$ positive correlation with $\mathrm{pH}$ and a negative correlation with $\mathrm{NO}_{3}-\mathrm{N}$, while in SERO phytoplankton quantities were correlated positively with $\mathrm{NO}_{3}-\mathrm{N}$, SRP and $\mathrm{Mg}$ and negatively with water temperature. The vertical distribution of phytoplankton largely parallels the chlorophyll distribution in the lakes sampled for both the regional and the seasonal surveys.

According to the OECD method (Vollenweider \& Kerekes 1982) the average chlorophyll concentrations recorded in the lakes sampled in 1996 (Tab. 2) suggest that 14 lakes are ultraoligo-oligotrophic and two (NERO and GARZ) are mesotrophic. The annual maximum and average of chlorophyll concentrations (Tab. 3) suggest that Lake TREL and SERO are characterised by oligomesotrophic and oligotrophic conditions, respectively.

A trophic classification of the lakes sampled in 1996, using phytoplankton biovolume, was performed according to the method proposed by Heinonen (1980). As this is based on mid summer phytoplankton biovolumes, it can be applied to lakes sampled once during the vegetation period. According to this method, 12 lakes with algal biovolumes lower than $200 \mathrm{~mm}^{3} \mathrm{~m}^{-3}$ (Tabs 1 and 2) were classed as ultraoligotrophic, while lakes NERO, SGIU, GARZ and RITO were deemed oligotrophic. Lakes TREL and SERO were classified using different methods based on phytoplankton biovolume, each approach confirming the differences between the two lakes (Tabs 1 and 3). Lake TREL was classified as oligotrophic (Vollenweider 1968; Heinonen 1980; Rott 1984) or oligo-mesotrophic (Brettum 1989), while Lake SERO was classed as ultraoligotrophic (Tab. 3) according to all methods used.

Trophic classification based on relative abundances of littoral diatoms (Hofmann 1994) placed the majority of the lakes within the oligotrophic class (Trophic Index $<1.99$, Tab. 2). Although the variability of the Hoffman's Index allowed discrimination between oligotrophic and "strongly" oligotrophic lakes (Tab. 2), only $40 \%$ of the lakes sampled in 1996 showed a correspondence between the trophic level based on littoral diatoms and that based on TP, chlorophyll and phytoplankton biovolume (Tab. 2). The classification based on littoral diatoms confirmed the slightly higher trophic level exhibited by TREL relative to SERO (average In$\operatorname{dex}=1.85$ and 1.56 respectively, Tab. 3 ).

\subsection{Phytoplankton-littoral diatom species composition and diversity}

In most lakes, flagellated Chrysophyceae and Dinophyceae accounted for the highest percentage of phytoplankton biovolume, typical for high mountain lakes, which are ice covered for 7 or more months per year (Nauwerck 1966; Tilzer 1972; Rott 1988; Brettum 1989). Among Chrysophyceae were a large number of small oligotraphentic taxa belonging to the genera Chromulina, Chrysococcus, Dinobryon, Mallomonas, Pseudokephyrion and Chrysolykos (Tab. 4), which were mainly uniformly distributed along the water column. Dinophyceae were dominated by two large species (Gymnodinium uberrimum and Peridinium cinctum) and several small taxa of the genera Gymnodinium and Peridinium (Tab. 4). 
Tab. 4. Species list of phytoplankton (relative abundance $>1 \%$ ) and littoral epilithic diatoms (relative abundance $>5 \%$ ). MA =Maximum abundance reached by the taxa; NL, NS = number of occurrences in the lakes sampled in 1996 (16 samples) and in the samples from lakes Tre Laghi (28 samples) and Serodoli (47 samples) respectively.

\begin{tabular}{|c|c|c|c|c|c|c|c|}
\hline \multirow[b]{2}{*}{ Taxon } & \multirow[b]{2}{*}{ Code } & \multicolumn{2}{|c|}{1996} & \multicolumn{2}{|c|}{ TREL } & \multicolumn{2}{|c|}{ SERO } \\
\hline & & MA & NL & MA & NS & MA & NS \\
\hline \multicolumn{8}{|l|}{ Cyanophyceae } \\
\hline Anabaena cf. planctonica BRUNN. & & & & 2.9 & 3 & & \\
\hline Oscillatoria sp. VAUCHER & & 9.6 & 1 & & & & \\
\hline \multicolumn{8}{|l|}{ Cryptophyceae } \\
\hline Cryptomonas cf. ovata EHREN. & CRYPOVAT & 5.3 & 2 & 29.9 & 15 & 0.5 & 2 \\
\hline Cryptomonas cf. obovata EHREN. & & 4.3 & 4 & & & & \\
\hline Cryptomonas erosa EHREN. & CRYPEROS & 57.9 & 10 & & & 63.7 & 26 \\
\hline Cryptomonas marssonii SKUJA & & 4.0 & 3 & & & & \\
\hline Cryptomonas pyrenoidifera GEITLER & CRYPPYRE & 4.3 & 1 & 15.9 & 9 & & \\
\hline Rhodomonas cf. lacustris PASCHER \& RUTTNER & & 8.1 & 5 & & & & \\
\hline Rhodomonas minuta SKUJA & RHODMINU & 1.8 & 8 & 1.9 & 16 & 32.6 & 29 \\
\hline \multicolumn{8}{|l|}{ Dinophyceae } \\
\hline Gymnodinium cf. lacustre SCHILLER & & 1.5 & 1 & 22.6 & 8 & & \\
\hline Gymnodinium cf. lantzschii UTERMÖHL & GYMNLANT & 6.4 & 9 & 27.9 & 13 & 2.5 & 14 \\
\hline Gymnodinium uberrimum (ALLMANN) KOFOID & GYMNUBER & 92.6 & 14 & 0.5 & 4 & & \\
\hline Gymnodinium sp. STEIN & GYMNsp01 & 4.1 & 1 & 5.8 & 5 & 9.6 & 14 \\
\hline Gyrodinium sp. KOFOID \& SWEZY & & & & 2.7 & 6 & 15.4 & 15 \\
\hline Peridinium cinctum PENARD & PERICINC & 51.0 & 4 & 0.9 & 4 & & \\
\hline Peridinium inconspicuum LEMM. & PERIINCO & 26.8 & 7 & 89.8 & 21 & 11.7 & 10 \\
\hline Peridinium umbonatum STEIN & PERIUMBO & 17.9 & 7 & & & & \\
\hline Sphaerodinium sp. WOLOS. & SPHEsp01 & & & 25.5 & 17 & & \\
\hline \multicolumn{8}{|l|}{ Euglenophyceae } \\
\hline Trachelomonas sp. EHREN. & & & & & & 3.3 & 1 \\
\hline \multicolumn{8}{|l|}{ Chrysophyceae } \\
\hline Chromulina sp. I ( $5 \mu \mathrm{m})$ CIENKOWSKY & CHROsp-5 & 5.8 & 7 & 3 & 10 & 2.8 & 3 \\
\hline Chromulina sp. II (4 - $7 \mu \mathrm{m})$ CIENKOWSKY & & 3.1 & 2 & 2 & 4 & 34.4 & 11 \\
\hline Chrysococcus cf. rufescens KLEBS & & & & 3.2 & 5 & 32.0 & 14 \\
\hline Chrysococcus sp. I (3.5 $\mu \mathrm{m})$ KLEBS & & & & 1.1 & 3 & & \\
\hline Chrysococcus sp. II (5-6 $\mu \mathrm{m})$ KLEBS & & 1.4 & 7 & 1.8 & 9 & 14.5 & 30 \\
\hline Chrysolykos skujae (NAUUWERCK) WILLÉN & & & & & & 0.6 & 4 \\
\hline Chrysosphaerella brevispina KORS̆IKOV & & & & 4.7 & 3 & 1.5 & 1 \\
\hline Dinobryon cylindricum var. alpinum IMHOF & & 2.1 & 7 & 11.9 & 11 & 4.9 & 12 \\
\hline Dinobryon sociale var. americanum (BRUNN.) BACHMANN & & 2.9 & 1 & & & & \\
\hline Kephyrion cf. boreale SKUJA & KEPHBORE & & & 4.1 & 1 & & \\
\hline Mallomonas acaroides PERTY & MALLACAR & 31.0 & 3 & & & & \\
\hline Mallomonas akrokomos RUTTNER & MALLAKRO & & & & & 2.2 & 8 \\
\hline Mallomonas $\mathrm{cf}$. tonsurata TEILING & MALLTONS & 9.3 & 3 & & & & \\
\hline Ochromonas sp. I $(10 \mu \mathrm{m})$ WYSSOTZKI & OCHRsp10 & & & 19.5 & 4 & 62.2 & 11 \\
\hline Ochromonas sp. II (20 $\mu \mathrm{m})$ WYSSOTZKI & & 7.5 & 5 & 3.3 & 2 & 9.5 & 3 \\
\hline Pseudokephyrion cf. tatricum (JURIŠ) STARMACH & & 17.6 & 8 & 4.8 & 10 & 12.7 & 15 \\
\hline Spiniferomonas cf. bourrelly TAKAHASHI & & 11.2 & 1 & & & 2.1 & 2 \\
\hline Stichogloea doederleinii (SCHMIDLE) WILLE & STICDOED & & & 3.9 & 10 & 74.2 & 25 \\
\hline Coccal Chrysophyceae $(5 \mu \mathrm{m})$ & & 0.5 & 1 & & & 4.3 & 5 \\
\hline Flagellated Chrysophyceae $(5 \mu \mathrm{m})$ & CHRFL-05 & 11.1 & 7 & 6 & 15 & 42.2 & 22 \\
\hline 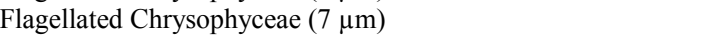 & CHRFL-07 & 3.6 & 5 & & & 38.7 & 19 \\
\hline Flagellated Chrysophyceae $(3-10 \mu \mathrm{m})$ & & 16.7 & 10 & 19.0 & 34 & 47.6 & 41 \\
\hline Flagellated Chrysophyceae $(12 \mu \mathrm{m})$ & CHRFL-12 & 7.7 & 2 & 28.5 & 4 & 3.7 & 2 \\
\hline Flagellated Chrysophyceae $(5 \times 7 \mu \mathrm{m})$ & FLAGsp57 & 22.5 & 9 & 22.9 & 14 & 1.7 & 3 \\
\hline \multicolumn{8}{|l|}{ Bacillariophyceae } \\
\hline Aulacoseira alpigena (GRUN.) KRAMMER & AUSEALPI & 1.0 & 6 & & & & \\
\hline Aulacoseira lirata (EHREN.) ROSS & & 2.6 & 3 & & & & \\
\hline Aulacoseira valida (GRUN.) KRAMMER & pAUSVALI & 5.7 & 6 & & & & \\
\hline Aulacoseira distans var. nivalis (W. SMITH) HAWORTH & pAUSDIni & 6.1 & 1 & & & & \\
\hline Stephanodiscus neoastraea HÅKANSSON \& HICKEL & STEDNEOA & 13.1 & 3 & & & & \\
\hline Synedra sp. EHREN. & & 2.5 & 7 & & & 1.1 & 3 \\
\hline Tabellaria flocculosa (ROTH) KÜTZ. & TABEFLOC & 2.0 & 4 & 2 & 3 & & \\
\hline
\end{tabular}


Tab. 4. Continuation.

\begin{tabular}{|c|c|c|c|c|c|c|c|}
\hline \multirow[b]{2}{*}{ Taxon } & \multirow[b]{2}{*}{ Code } & \multicolumn{2}{|c|}{1996} & \multicolumn{2}{|c|}{ TREL } & \multicolumn{2}{|c|}{ SERO } \\
\hline & & MA & NL & MA & NS & MA & NS \\
\hline \multicolumn{8}{|l|}{ Littoral epilithic taxa } \\
\hline Achnanthes acidoclinata LANGE-BERT. & ACHNACID & 28.8 & 16 & & & 16.4 & 5 \\
\hline Achnanthes altaica (PORETZKY) CLEVE-EULER & ACHNALTA & 21.7 & 13 & & & & \\
\hline Achnanthes helvetica LANGE-BERT. & ACHNHELV & 19.6 & 16 & & & 6.2 & 5 \\
\hline Achnanthes marginulata GRUN. & ACHNMARG & 24.3 & 17 & 6.1 & 5.0 & 12.1 & 5 \\
\hline Achnanthes cf. marginulata GRUN. (nov. sp. N. 2 \& 3 Julma Ölkky) & & 45.0 & 12 & & & 18.3 & 5 \\
\hline Achnanthes minutissima KÜTZING & & 74.9 & 16 & 29.1 & 5.0 & 8.5 & 5 \\
\hline Achnanthes saccula CARTER & & 5.9 & 9 & & & & \\
\hline Achnanthes subatomoides (HUSTEDT) L.-B. \& ARCH. & ACHNSUAT & 10.2 & 15 & 16.4 & 5.0 & & \\
\hline Aulacoseira alpigena (GRUN.) KRAMMER & & 8.1 & 10 & & & & \\
\hline Aulacoseira distans var. nivalis (W. SMITH) HAWORTH & & 5.3 & 10 & & & & \\
\hline Brachysira brebissonii ROSS & BRACBREB & 25.6 & 16 & 11.5 & 5.0 & 35.6 & 5 \\
\hline Brachysira garrensis LANGE-BERT. \& KRAMMER & & & & & & 14.2 & 5 \\
\hline Brachysira neoexilis LANGE-BERT. & BRACNEOE & 59.8 & 14 & 14.8 & 5.0 & & \\
\hline Chamaepinnularia mediocris KRASSKE & & 11.1 & 6 & & & & \\
\hline Encyonema minutum (HILSE) MANN & ENCYMINU & & & 5.9 & 5.0 & & \\
\hline Encyonopsis cf. krammeri REICHARDT & ENCOKRAM & 30.2 & 7 & & & & \\
\hline Encyonema cf. ventricosum var. angusta KRAMMER & & & & 13.1 & 4.0 & & \\
\hline Denticula tenuis KÜTZING & & & & 10.7 & 5.0 & & \\
\hline Diadesmis gallica var. perpusilla (GRUN.) LANGE-BERT. & & & & & & 8.0 & 2 \\
\hline Fragilaria exigua GRUN. & EUTIEXIG & 24.9 & 11 & & & 5.3 & 5 \\
\hline Eunotia faba EHRENBERG & & 5.3 & 3 & & & & \\
\hline Eunotia fallax sensu HUSTEDT & & 6.0 & 8 & & & & \\
\hline Eunotia groenlandica LANGE-BERT. \& NÖRPEL & & 6.2 & 9 & & & & \\
\hline Eunotia praerupta EHREN. var. praerupta & & & & 5.1 & 4.0 & & \\
\hline Eunotia rhomboidea HUSTEDT & & 15.3 & 8 & & & & \\
\hline Fragilaria construens f. venter (EHREN.) HUSTEDT & & 6.3 & 5.0 & & & & \\
\hline Fragilaria pinnata EHREN. & FRAGPINN & 6.6 & 3.0 & & & & \\
\hline Gomphonema productum (GRUN.) LANGE-BERT. & & 17.7 & 15 & & & & \\
\hline Navicula submolesta HUSTEDT & & 5.4 & 7 & & & & \\
\hline Nitzschia perminuta (GRUN.) PERGALLO & NITZPERM & 10.7 & 11 & & & & \\
\hline Pinnularia sinistra KRAMMER & & 11.0 & 9 & & & & \\
\hline \multicolumn{8}{|l|}{ Xanthophyceae } \\
\hline Ophiocytium parvulum (PERTY) A. BRAUN & OPHIPARV & & & & & 1.8 & 6 \\
\hline Tetraedriella patiens RAMBERG (1978) & TETLPATI & & & & & 11.8 & 8 \\
\hline \multicolumn{8}{|l|}{ Chlorophyceae (sensu lato) } \\
\hline Didymocystis sp. KORŠIKOV & & & & 1.4 & 5 & & \\
\hline Elakatothrix genevensis HINDÁK & & & & & & 3.2 & 15 \\
\hline Eutetramorus cf. nygaardii KOMÁREK & & & & & & 4.3 & 3 \\
\hline Eutetramorus fottii KOMÁREK & EUTEFOTT & 16.5 & 10 & 3.9 & 12 & 35.3 & 26 \\
\hline Oocystis parva W. \& G. S. WEST & OOCYPARV & 32.7 & 6 & & & 64.1 & 36 \\
\hline Pediastrum boryanum (TURP.) MENEGHINI & & & & & & 1.3 & 1 \\
\hline Pseudodictyosphaerium minusculus HINDÁK & PSDICMIN & 11.5 & 3 & 36 & 25 & & \\
\hline Scenedesmus aculeolatus REINSCH & SCENACUL & & & 32.9 & 1 & & \\
\hline Tetrachlorella incerta HINDÁK & TCHLINCE & 98.2 & 2 & & & & \\
\hline Tetraedron minimum fa. tetralobulatum REINSCH & & 6.0 & 3 & & & & \\
\hline Thorakochloris nygaardii KOMÁREK & & & & 1.4 & 3 & & \\
\hline Trochiscia sp. KÜTZING & TROCsp01 & & & & & 2.1 & 9 \\
\hline Coccal I $(9 \mu \mathrm{m})$ & GCOCCnak & 7.2 & 5 & & & 4.2 & 2 \\
\hline Coccal II $(10 \mu \mathrm{m})$ & & & & 11.3 & 12 & 8.8 & 15 \\
\hline \multicolumn{8}{|l|}{ Zygnemataceae } \\
\hline Arthrodesmus octocorne (ARCHER) EHREN. & ARTHOCTO & 1.0 & 2 & & & & \\
\hline Cosmarium abbreviatum RACIB. & & 1.5 & 1 & & & & \\
\hline Cosmarium asphaerosporum var. strigosum NORDST. & COSMASst & 29.8 & 1 & 96.7 & 26 & & \\
\hline Cosmarium subcostatum NORDST. & & & & & & 1.5 & 1 \\
\hline Euastrum bidentatum NÄGELI & & 3.0 & 1 & & & & \\
\hline Gonatozygon aculeatus HAST. & & 4.4 & 3 & & & & \\
\hline Hyalotheca dissiliensis (SMITH) BRÉB. in RALFS & & 1.1 & 3 & & & & \\
\hline Mougeotia sp. AGARDH & & 6.8 & 2 & & & & \\
\hline Penium spirostriolatum var. spirostriolatum BARK. & & 12.8 & 1 & & & & \\
\hline Staurastrum polymorphum (RALFS) BRÉB. & & & & 1.1 & 8 & & \\
\hline Staurodesmus cf. incus (BREB.) TEILING & & 6.7 & 2 & & & & \\
\hline Staurodesmus triangularis (LAGERHEIM) TEILING & & & & 1.3 & 8 & & \\
\hline Xanthidium alpinum SCHMIDLE & & 4.8 & 8 & & & 6.0 & 10 \\
\hline
\end{tabular}


The commonly observed Gymnodinium uberrimum, Peridinium inconspicuum and $P$. umbonatum showed a clear preference for deeper waters, while Peridinium cinctum was abundant only in shallow waters of lakes sampled in early summer (RITO, ARTU, SMAL). Cryptophyceae were present with cosmopolitan species (like Cryptomonas erosa and Rhodomonas minuta) in all lakes, but contributed only small proportions of the total biovolume. However, in some deep lakes (GARZ and SERO) this algal group was more important, reaching abundances of up to $60 \%$ of the total in the deep waters. Coccal green algae (like Eutetramorus fottii and Oocystis parva) were common in the majority of lakes, but they rarely reached relative abundances higher than $10 \%$. However, in Lake GHIA more than $90 \%$ of the biovolume was due to Tetrachlorella incerta. Desmids reached abundances higher than 5\% only in lakes NERO and SGIU while in all other lakes these were scarce, which is usually the case in high altitude lakes (Nauwerck 1966; Pechlaner 1971; Pfister 1988). Cyanophyceae and planktonic diatoms were particularly scarce in all lakes sampled in 1996 (Tab. 4).

The phytoplankton assemblages found in the lakes sampled during 1997 and 1998 were generally similar to that of the lakes sampled in 1996 (Tab. 4). In early summer (June 1997) both lakes showed the dominance of small flagellates, as typical for high mountain lakes after the ice melting (Pechlaner 1971). In July an increase in the abundance of coccal green algae was observed in both lakes, but after August the two lakes developed in a completely different manner. In Lake TREL the small desmid Cosmarium asphaerosporum var. strigosum increased progressively, reaching $96 \%$ in October, with $15 \times 10^{6}$ cell $1^{-1}$. This taxon remained abundant during the whole winter (36\% in February 1998) and Dinophyceae became the dominant group again (80\%) only in June 1998. In Lake SERO Chrysophyceae were dominant during the whole ice-free period except in August, when $63 \%$ of the phytoplankton biovolume was due to the coccal green algae Eutetramorus fottii and Oocystis parva. Desmids remained sporadic for the whole sampling period.

The littoral diatom communities of the lakes studied were dominated by alpine, oligotraphentic and acidophilous taxa, mainly belonging to the genera $\mathrm{Na}$ vicula, Eunotia, Pinnularia, Achnanthes and Cymbella sensu lato (Tab. 4, Tolotti 2001, in press). 176 (86\%) of the 204 taxa identified in the stone and debris samples are included in the German red list for diatoms (LangeBertalot \& Steindorf 1996), 11 as extremely rare and 88 as endangered to different degree. Seasonal variations in lakes TREL and SERO were observed but not pronounced and involved mainly subdominant and rare taxa (Tolotti 2001, in press).

High Shannon Index values (range $=1.7-5$, Tabs 2 and 3) confirm the high species richness and diversity of the diatom communities of the majority of the lakes.
The Shannon Index values calculated for phytoplankton were lower $(0.2-3.8$, Tabs 2 and 3$)$ due to the lower numbers of taxa recorded and as a result of the higher inter-specific dominance compared with the littoral diatoms (Tabs 2 and 4). The lowest values were recorded in two lakes of the Adamello mountain range (SMAN and GHIA, Tab. 2), where more than $90 \%$ of the algal biovolume were due to a singular taxon. In general, no correspondence could be found between phytoplankton and diatom diversity in the different lakes and no significant correlation was found between algal species diversity and any environmental variable. Lake TREL exhibited slightly higher Shannon Index values for both phytoplankton and diatoms compared to SERO, but the highest diversity of the two algal communities was found in both the lakes in early summer (Tab. 3).

\subsection{Sample ordination}

Numerical analyses carried out on phytoplankton and littoral diatom assemblages separately resulted in different sample ordinations (Fig. 2, Tolotti 2001, in press), as a result of the different ecological characteristics of the two algal communities. This paper focuses on the ordinations obtained from the phytoplankton species composition, and compares these with the results of the diatom analyses.

The lakes sampled in 1996 were significantly (eigenvalues $>0.5$ ) classified by TWINSPAN into one large group characterised by dinoflagellates (B and $\mathrm{C}$ in Tab. 5 and Fig. 2) and two groups dominated by coccal green algae (A and D in Tab. 5 and Fig. 2). The dinoflagellates-lakes are further divided into two groups. Group B is characterised by large species - Peridinium cinctum and Gymnodinium uberrimum - and the Chrysophycea Mallomonas acaroides, while group $\mathrm{C}$ is characterized by Peridinium inconspicuum and P. umbonatum. The large Dinophyceae were characteristic of mid altitude lakes with significantly $(\mathrm{p}<0.05)$ higher alkalinity and TP (Group B in Tab. 5), while the small Peridinium species showed higher abundances in lakes located in the Presanella mountain range characterized by higher altitude, greater depth (average $=22 \mathrm{~m}$ ), lower alkalinity and nutrient levels (Group C in Tab. 5). The coccal green algae Oocystis parva and Pseudodictyosphaerium minusculum were dominant in SGIU, a shallow and relatively warm lake located beneath 2000 $\mathrm{m}$ a.s.l., with the highest conductivity, SRP and $\mathrm{SO}_{4}$ values across the study lakes (Tabs 2 and 5). Tetrachlorella incerta was dominant in high altitude lakes with high $\mathrm{NH}_{4}-\mathrm{N}$ concentrations (ROTO and GHIA, Tabs 2 and 5).

In the RDA ordination (Fig. 3) axis 1 and $2\left(\lambda_{1}=\right.$ $\left.0.281 ; \lambda_{2}=0.130\right)$ accounted for $69 \%$ of the total variance in species abundances as constrained by the environmental variables. The eigenvalues were highly significant $(p<0.005)$ according to the Monte Carlo per- 


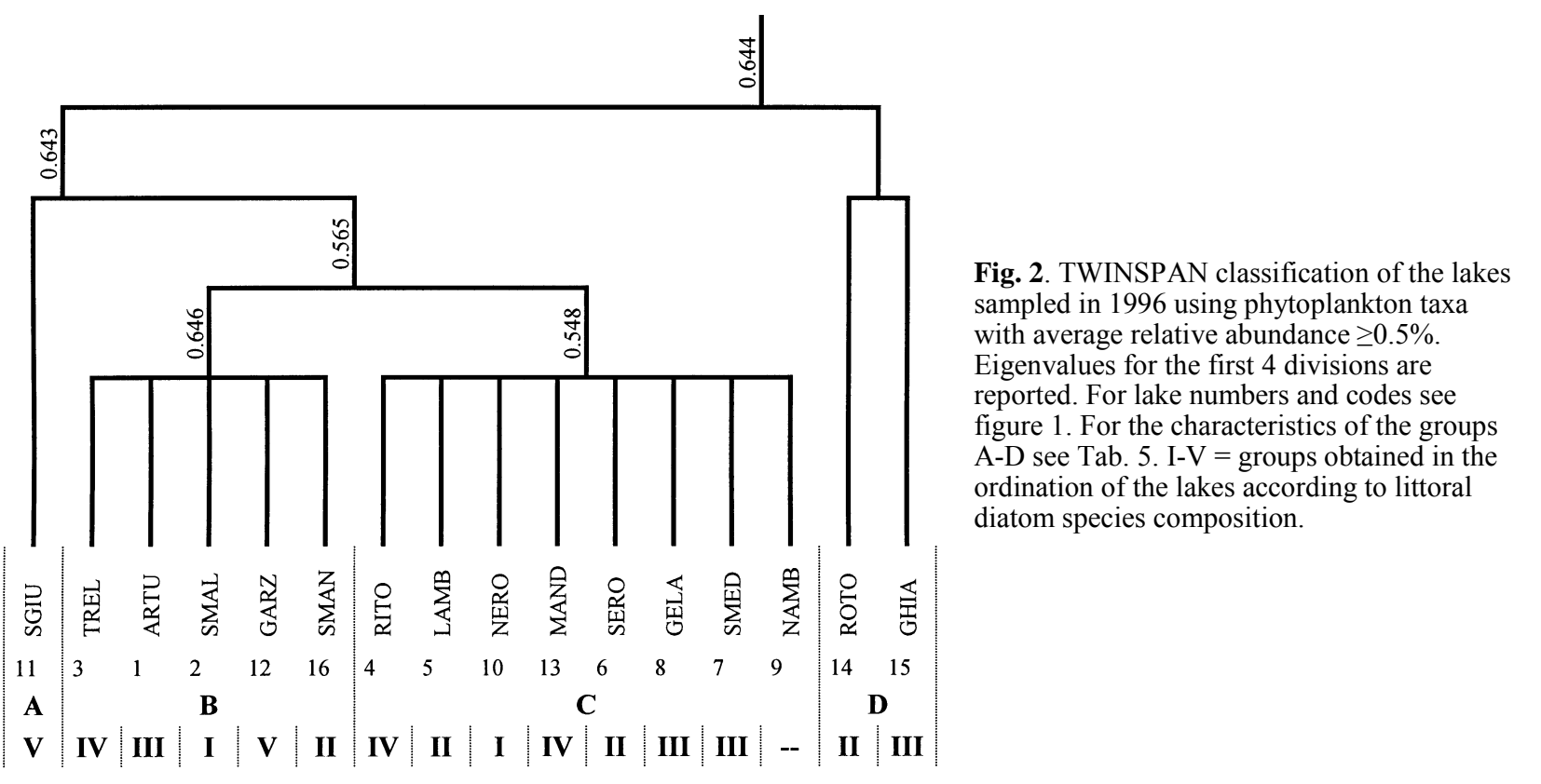

Tab. 5. Characterization of the groups of lakes sampled during 1996 separated by TWINSPAN according to phytoplankton taxa with relative abundances $>0.5 \%$. Labels refer to the groups identified until level 3 (Fig. 2). Lake codes as in figure 1, phytoplankton and littoral diatom taxon codes as in table 4 . $\mathrm{GR}=$ taxonomical group: $\mathrm{BA}=$ Bacillariophyceae; $\mathrm{CHL}=$ Chlorophyceae; $\mathrm{CHR}=$ Chrysophyceae; $\mathrm{CRY}=$ Cryptophyceae; $\mathrm{DI}=$ Dinophyceae; $\mathrm{XA}=$ Xanthophyceae; ZY = Zygnemataceae.

\begin{tabular}{|c|c|c|c|c|c|c|c|}
\hline GROUP & $\begin{array}{l}\text { Lake } \\
\text { code }\end{array}$ & GR & Phytoplankton & $\begin{array}{c}\text { Average } \\
\text { Rel. Ab. (\%) }\end{array}$ & $\begin{array}{l}\text { Morphological and physico-chemical } \\
\text { characterization }\end{array}$ & $\begin{array}{l}\text { Littoral } \\
\text { diatoms }\end{array}$ & $\begin{array}{c}\text { Average } \\
\text { Rel. Ab. (\%) }\end{array}$ \\
\hline A & SGIU & $\begin{array}{c}\text { CHL } \\
\text { CHL } \\
\text { BA } \\
\text { CRY } \\
\text { ZY } \\
\text { ZY }\end{array}$ & $\begin{array}{c}\text { OOCYPARV } \\
\text { PSDIMINU } \\
\text { AUSEDIni } \\
\text { CRYPMARS } \\
\text { COSMASst } \\
\text { ARTHOCTO }\end{array}$ & $\begin{array}{c}33 \\
12 \\
6 \\
4 \\
3 \\
1\end{array}$ & $\begin{array}{c}\text { Lowest altitude } \\
\text { Shallow water, aquatic plants } \\
\text { Large catchment area } \\
\text { Highest water temperature } \\
\text { Highest conductivity, TP and } \mathrm{SO}_{4}\end{array}$ & $\begin{array}{l}\text { ENCOKRAM } \\
\text { NITZPERM }\end{array}$ & $\begin{array}{l}30 \\
11\end{array}$ \\
\hline B & $\begin{array}{l}\text { TREL } \\
\text { ARTU } \\
\text { SMAL } \\
\text { GARZ } \\
\text { SMAN }\end{array}$ & $\begin{array}{c}\text { DI } \\
\text { DI } \\
\text { CHR } \\
\text { BA } \\
\text { BA }\end{array}$ & $\begin{array}{l}\text { GYMNUBER } \\
\text { PERICINC } \\
\text { MALLACAR } \\
\text { AUSEVALI } \\
\text { TABEFLOC }\end{array}$ & $\begin{array}{c}41 \\
11 \\
8 \\
3 \\
1\end{array}$ & $\begin{array}{c}\text { Mid altitude and depth } \\
\text { Highest alkalinity } \\
\text { High TP }\end{array}$ & $\begin{array}{l}\text { BRACNEOE } \\
\text { GONEPROD } \\
\text { TABEFLOC } \\
\text { GONEGRAC } \\
\text { ENCYMINU }\end{array}$ & $\begin{array}{l}17 \\
2 \\
1 \\
1 \\
1\end{array}$ \\
\hline $\mathrm{C}$ & $\begin{array}{l}\text { RITO } \\
\text { LAMB } \\
\text { NERO } \\
\text { MAND } \\
\text { SERO } \\
\text { GELA } \\
\text { SMED } \\
\text { NAMB }\end{array}$ & $\begin{array}{c}\text { DI } \\
\text { DI } \\
\text { DI } \\
\text { CHL } \\
\text { CHR } \\
\text { XA } \\
\text { CRY }\end{array}$ & $\begin{array}{c}\text { PERIINCO } \\
\text { PERIUMBO } \\
\text { GYMNLANT } \\
\text { GCOCCnak } \\
\text { MALLTONS } \\
\text { XANTALPI } \\
\text { RHODMINU }\end{array}$ & $\begin{array}{l}9 \\
5 \\
2 \\
2 \\
2 \\
1 \\
1\end{array}$ & $\begin{array}{c}\text { Location in the Presanella group } \\
\text { High depth } \\
\text { Low alkalinity } \\
\text { Low conductivity and TP }\end{array}$ & $\begin{array}{l}\text { ACHNACID } \\
\text { EUTIEXIG } \\
\text { NAVIKRAS }\end{array}$ & $\begin{array}{l}8 \\
6 \\
1\end{array}$ \\
\hline $\mathrm{D}$ & $\begin{array}{l}\text { ROTO } \\
\text { GHIA }\end{array}$ & $\begin{array}{l}\text { CHL } \\
\text { BA }\end{array}$ & $\begin{array}{l}\text { TCHLINCE } \\
\text { STEDNEOA }\end{array}$ & $\begin{array}{c}55 \\
7\end{array}$ & $\begin{array}{c}\text { Location in the Adamello group } \\
\text { Sampling at the end of summer } \\
\text { High altitude } \\
\text { Highest } \mathrm{NH}_{4}-\mathrm{N}\end{array}$ & $\begin{array}{l}\text { ACHNMARG } \\
\text { ACHNALTA } \\
\text { ACHNHELV } \\
\text { DIATMESO }\end{array}$ & $\begin{array}{c}16 \\
13 \\
13 \\
2\end{array}$ \\
\hline
\end{tabular}

mutation test carried out on the first axis. The RDA reflects the TWINSPAN ordination (which was based on phytoplankton species composition only) and can be explained predominantly by gradients of $\mathrm{NO}_{3}-\mathrm{N}$ and $\mathrm{NH}_{4}-\mathrm{N}$, altitude, $\mathrm{pH}$ and depth. Lakes ROTO and GHIA (Group D in Tab. 5) are clearly distinct from the other lakes, due to the dominance of the Tetrachlorella incerta and in terms of altitude, $\mathrm{NH}_{4}-\mathrm{N}$ and $\mathrm{pH}$. The proximate position of lakes SMAN and GARZ is due to the high relative abundance of Gymnodinium uberrimum in both lakes and as a result of their great depths. Lakes ascribed to TWINSPAN groups B and C are dis- 


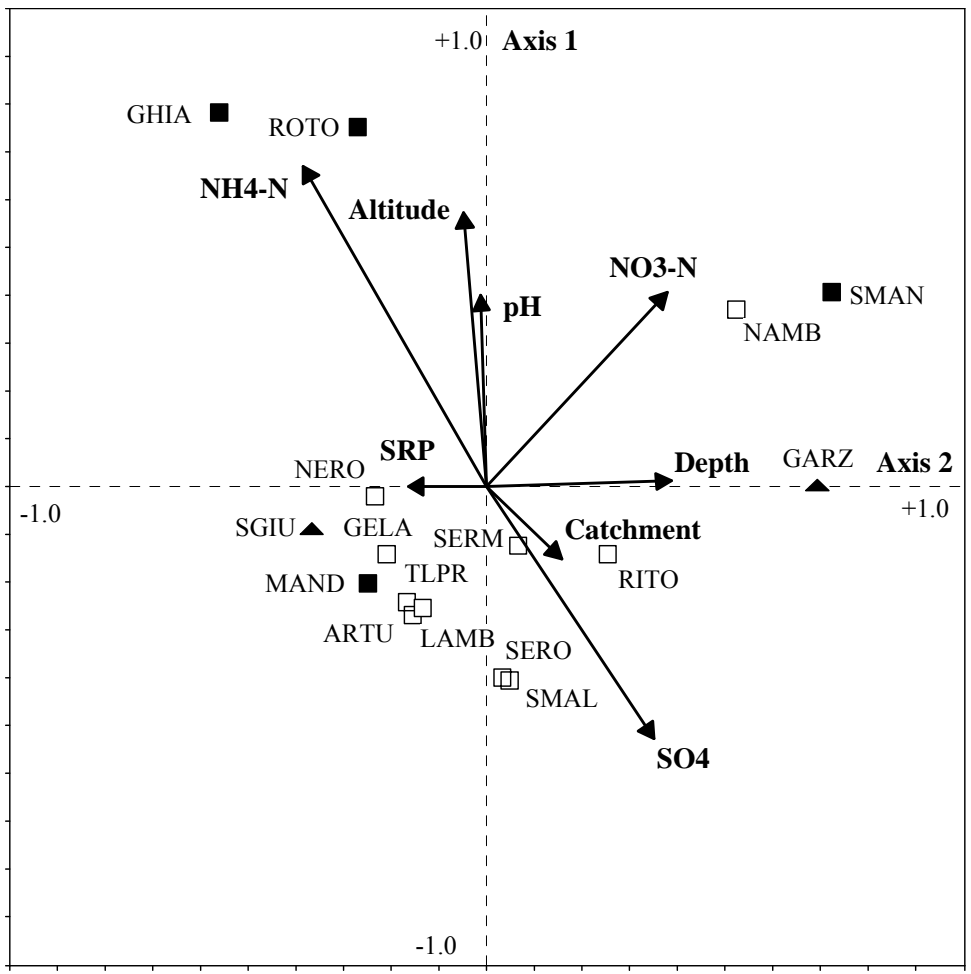

Fig. 3. Ordination of phytoplankton samples from the 16 lakes studied in 1996 in relation to the 8 most correlated environmental variables based on redundancy analysis $\left(\lambda_{1}=0.281 ; \lambda_{2}=0.130\right)$. For lake codes see Fig. 1. $\square=$ Presanella; $\mathbf{\square}=$ Adamello; $\Delta=$ Val Genova.

tributed differently when both species composition and environmental variables are taken into account. Nevertheless, with the exception of lakes NAMB (a deep lake with the highest $\mathrm{NO}_{3}-\mathrm{N}$ concentrations, Tab. 2), SMAN and GARZ, the lakes belonging to the two groups are located in the ordination space corresponding to low $\mathrm{NO}_{3}-\mathrm{N}$ and low pH. Lake SGIU (group A in Tab. 5) is not separated as clearly as it appears following TWINSPAN analysis, even being plotted in the area corresponding to low depth and higher SRP (Tab. 2).

The grouping of the lakes according to their phytoplankton assemblages can be linked to characteristic littoral diatom taxa (Tab. 5), even though the RDA based on diatoms resulted in a different lake distribution (Tolotti 2001, in press). The distinctive nature of SGIU within this dataset is confirmed by the dominance of Encyonopsis krammeri. Lakes ROTO and GHIA were characterized by several Achnanthes species with similar abundances. The lakes dominated by large dinoflagellates were characterized by peak abundance of Brachysira neoexilis, while the small dinoflagellates characterizing the group $\mathrm{C}$ were related to two acidophilous species (Achnanthes acidoclinata and Eunotia exigua), a result of the low alkalinity and mineralization level of the lakes included within this group (Tab. 2).

TWINSPAN ordinations of phytoplankton samples collected from the lakes TREL and SERO during 1997 and 1998 confirmed the presence of a clear seasonal succession in both lakes, as exemplified by the grouping of samples collected at certain sampling dates (Tabs 6 and 7). Five different phytoplankton assemblages were identified in TREL (Tab. 6), corresponding to early summer (groups A, B and C), mid summer-autumn (D) and late winter (E) respectively. The samples collected in June 97 and 98, few days after the ice off, were characterized by the dominance of small Cryptophyceae and Peridinium inconspicuum, respectively. July 97 (group B) is characterized by the association of small Chrysophyceae and coccal green algae (Pseudodictyosphaerium minusculum and Scenedesmus aculeolatus) and represents an intermediate stage between June 97 and the midsummer-autumn period, dominated by the small desmid, Cosmarium asphaerosporum var. strigosum. Late winter is again characterized by the abundance of small flagellated Chrysophyceae and Dinophyceae.

These phytoplankton associations may be linked to specific environmental conditions. The dominance of dinoflagellates in June 98 was related to low alkalinity and $\mathrm{pH}$ values while the abundance of small flagellates in winter was related to low temperature and $\mathrm{NO}_{3}-\mathrm{N}$ and to higher $\mathrm{pH}$ (Tab. 3). The intermediate conditions in July are confirmed by the absence of particular environmental features, while the dominance of Cosmarium asphaerosporum var. strigosum is related to the highest water temperature and $\mathrm{pH}$ values and to the lowest $\mathrm{NO}_{3}$ $\mathrm{N}$ concentrations (Tab. 3 ).

The TWINSPAN ordination of the phytoplankton samples collected from Lake SERO confirmed the poorly developed algal succession in this lake, as highlighted by the separation of all samples into three 
Tab. 6. Characterization of the samples from Lake Tre Laghi (collected at different depths during 1997- 98) separated by TWINSPAN according to phytoplankton species with relative abundances $>0.5 \%$. Labels refer to the lakes groups identified until level 4. $\mathrm{GR}=$ taxonomical group; $\mathrm{BA}=$ Bacillariophyceae; $\mathrm{CHL}=$ Chlorophyceae; $\mathrm{CHR}=$ Chrysophyceae; $\mathrm{CRY}=$ Cryptophyceae; DI = Dinophyceae; XA = Xanthophyceae; $Z Y=$ Zygnemataceae. Phytoplankton and littoral diatom taxon codes as in table 4 . TLP = trophic level according to average phytoplankton biovolume (Brettum 1989); TLD = trophic according to littoral diatoms (Hofmann 1994). $\mathrm{U}=$ ultraoligotrophic; $\mathrm{O}=$ oligotrophic; $\mathrm{OM}=$ oligomesotrophic; $\mathrm{M}=$ mesotrophic.

\begin{tabular}{|c|c|c|c|c|c|c|c|c|c|}
\hline GROUP & Sampling month & GR & Phytoplankton & $\begin{array}{c}\text { Average } \\
\text { Rel. Ab. (\%) }\end{array}$ & $\begin{array}{l}\text { Physico-chemical } \\
\text { characterization }\end{array}$ & $\begin{array}{l}\text { Littoral } \\
\text { diatoms }\end{array}$ & $\begin{array}{c}\text { Average } \\
\text { Rel. Ab. (\%) }\end{array}$ & TLP & TLD \\
\hline A & June 1997 & $\begin{array}{l}\text { CRY } \\
\text { CRY } \\
\text { CHR }\end{array}$ & $\begin{array}{l}\text { CRYPOVAT } \\
\text { CRYPPYRE } \\
\text { KEPHBORE }\end{array}$ & $\begin{array}{c}19 \\
10 \\
1\end{array}$ & $\begin{array}{c}\text { Lowest alkalinity } \\
\text { Highest } \mathrm{NO}_{3}-\mathrm{N} \text { and } \mathrm{NH}_{4}-\mathrm{N} \\
\text { Lowest TP }\end{array}$ & -- & -- & $\mathrm{O}$ & --- \\
\hline B & July 1997 & $\begin{array}{l}\text { CHR } \\
\text { CHL } \\
\text { CHL } \\
\text { CHR }\end{array}$ & $\begin{array}{c}\text { FLAGsp57 } \\
\text { PSDICMIN } \\
\text { SCENACUL } \\
\text { CHROsp-5 }\end{array}$ & $\begin{array}{c}19 \\
12 \\
8 \\
4\end{array}$ & $\begin{array}{c}\text { No relevant feature } \\
\text { Mid physico-chemical } \\
\text { values }\end{array}$ & $\begin{array}{l}\text { BRACNEOE } \\
\text { FRUSCRAS } \\
\text { bAUSVALI }\end{array}$ & $\begin{array}{c}15 \\
1 \\
1\end{array}$ & U & $\mathrm{O}$ \\
\hline $\mathrm{C}$ & June 1998 & $\begin{array}{c}\text { DI } \\
\text { CHR } \\
\text { DI }\end{array}$ & $\begin{array}{l}\text { PERIINCO } \\
\text { CHRSBREV } \\
\text { GYMNsp01 }\end{array}$ & $\begin{array}{c}46 \\
3 \\
2\end{array}$ & $\begin{array}{l}\text { Low } \mathrm{pH} \text { and alkalinity } \\
\text { High } \mathrm{NO}_{3}-\mathrm{N} \text { and } \mathrm{NH}_{4}-\mathrm{N}\end{array}$ & $\begin{array}{l}\text { ACHNBIAS } \\
\text { FRAGPINN } \\
\text { ACHNHELV } \\
\text { ACHNACID } \\
\text { DIATMESO } \\
\text { NITZHANT }\end{array}$ & $\begin{array}{l}7 \\
7 \\
4 \\
2 \\
1 \\
1\end{array}$ & $\mathrm{O}$ & OM \\
\hline D & $\begin{array}{l}\text { August } 1997 \\
\text { September } 1997 \\
\text { October } 1997\end{array}$ & $\mathrm{ZY}$ & COSMASst & 62 & $\begin{array}{c}\text { Highest average temperature } \\
\text { High pH } \\
\text { Lowest } \mathrm{NO}_{3}-\mathrm{N} \text { and } \mathrm{NH}_{4}-\mathrm{N}\end{array}$ & $\begin{array}{c}\text { BRACBREB } \\
\text { EUTIPRpr } \\
\text { FRAGCOve } \\
\text { ACHNMARG } \\
\text { FRAGEXIG } \\
\text { EUTIGLAC }\end{array}$ & $\begin{array}{l}7 \\
5 \\
4 \\
3 \\
2 \\
1\end{array}$ & $\begin{array}{c}\mathrm{O} \\
\mathrm{OM} \\
\mathrm{M}\end{array}$ & $\begin{array}{l}\mathrm{O} \\
\mathrm{O} \\
\mathrm{O}\end{array}$ \\
\hline E & Februar 1998 & $\begin{array}{c}\text { CHR } \\
\text { CHR } \\
\text { DI }\end{array}$ & $\begin{array}{l}\text { CHRFL-12 } \\
\text { OCHRsp10 } \\
\text { SPHEsp01 }\end{array}$ & $\begin{array}{c}19 \\
11 \\
2\end{array}$ & $\begin{array}{l}\text { Lowest average temperature } \\
\text { Highest alkalinity and } \\
\text { conductivity }\end{array}$ & -- & -- & $\mathrm{O}$ & --- \\
\hline
\end{tabular}

Tab. 7. Characterization of the samples from Lake Serodoli (collected at different depths during 1997-98) separated by TWINSPAN according to phytoplankton species with relative abundances $>0.5 \%$. Labels refer to the lakes groups identified until level 4. Abbreviations as in table6.

\begin{tabular}{|c|c|c|c|c|c|c|c|c|c|}
\hline GROUP & Sampling month & GR & Phytoplankton & $\begin{array}{c}\text { Average } \\
\text { Rel. Ab. (\%) }\end{array}$ & $\begin{array}{l}\text { Physico-chemical } \\
\text { characterization }\end{array}$ & $\begin{array}{l}\text { Littoral } \\
\text { diatoms }\end{array}$ & $\begin{array}{c}\text { Average } \\
\text { Rel. Ab. }(\%)\end{array}$ & TLP & TLD \\
\hline \multirow[t]{4}{*}{ A } & June 1997 & DI & PERIINCO & 5 & Lowest $\mathrm{pH}$ and alkalinity & ACHNBIAS & 9 & $\mathrm{U}$ & --- \\
\hline & June 1998 & XA & TETLPATI & 4 & Highest $\mathrm{NO}_{3}-\mathrm{N}$ and $\mathrm{NH}_{4}-\mathrm{N}$ & EUTIEXI & 5 & $\mathrm{U}$ & $\mathrm{O}$ \\
\hline & & $\mathrm{CHL}$ & TROCsp01 & 2 & Highest SRP and TP & & & & \\
\hline & & $\mathrm{CHR}$ & MALLAKRO & 2 & & & & & \\
\hline \multirow[t]{4}{*}{$\mathrm{B}$} & July 97 & $\mathrm{CHR}$ & STICDOER & 27 & Highest average temperature & BRACGARR & 12 & $\mathrm{U}$ & $\mathrm{O}$ \\
\hline & August 97 & CHL & EUTEFOTT & 9 & Mid physico-chemical values & ACHNACID & 8 & $\mathrm{U}$ & \\
\hline & Sptember 97 & $\mathrm{CHL}$ & OOCYPARV & 5 & Highest pH & ACHNSUAT & 2 & $\mathrm{U}$ & $\mathrm{O}$ \\
\hline & October 97 & $\mathrm{CHR}$ & CHRFL-07 & 4 & Lowest $\mathrm{NO}_{3}-\mathrm{N}$ and $\mathrm{NH}_{4}-\mathrm{N}$ & BRACNEOE & 1 & $\mathrm{U}$ & $\mathrm{O}$ \\
\hline \multirow[t]{3}{*}{$\mathrm{C}$} & March 1998 & $\mathrm{CHR}$ & OCHRsp10 & 47 & Lowest average temperature & --- & --- & $\mathrm{U}$ & $\mathrm{O}$ \\
\hline & & $\mathrm{CHR}$ & CHRFL-05 & 18 & High $\mathrm{NO}_{3}-\mathrm{N}$ and $\mathrm{NH}_{4}-\mathrm{N}$ & & & & \\
\hline & & CRY & CRYPEROS & 16 & High SRP and TP & & & & \\
\hline
\end{tabular}

groups only (A, B and $\mathrm{C}$ in Tab. 7), corresponding to early summer, mid summer-autumn and late winter, respectively. The samples of June 97 and 98 are included in the same group (A, characterized by Peridinium inconspicuum and the Xanthophycea Tetraedriella patiens), illustrating the less pronounced interannual differences relative to TREL. The samples collected from July to October were also included in a single group (B), characterized by the association of the coccal
Chrysophycea Stichogloea doederleinii and the green algae Oocystis parva and Eutetramorus fottii. Small flagellated Chrysophyceae were abundant in this lake throughout the whole year. As in TREL winter conditions (group C) are also characterised by high abundances of flagellated algae.

In Lake SERO, the early summer phytoplankton assemblage was related to the lowest $\mathrm{pH}$ and alkalinity values and to the highest nutrient concentrations. The 

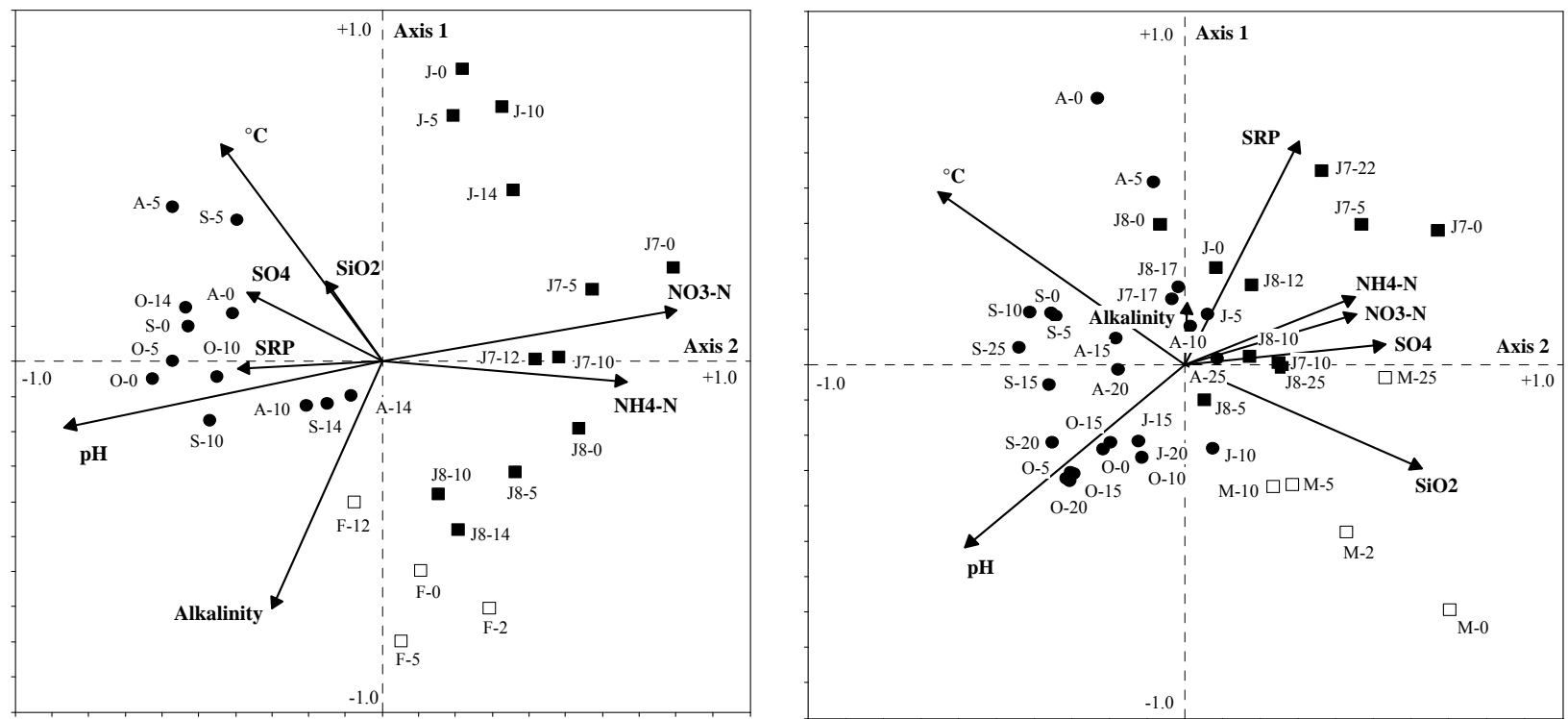

Fig. 4. Ordination of phytoplankton samples in lakes Tre Laghi (left panel) and Serodoli (right panel) in relation to the 8 most correlated environmental variables based on the redundancy analysis $\left(\lambda_{1}=0.588\right.$ and $0.122 ; \lambda_{2}=0.065$ and 0.122 respectively). For sampling month abbreviations see table 3 . Numbers in the labels indicate the corresponding sampling depth. $\boldsymbol{\square}=$ early summer; $\bullet=$ summer-autumn; $\square=$ winter.

dominance of coccal taxa during summer and autumn was related to the high water temperatures and $\mathrm{pH}$ and to the low $\mathrm{NH}_{4}-\mathrm{N}$ and $\mathrm{NO}_{3}-\mathrm{N}$ concentrations (Tabs 3 and 7). In winter the lowest temperatures and the highest nutrient concentrations were evident.

TWINSPAN sample classification of both lakes were largely confirmed by the CANOCO ordinations (Fig. 4), where the first two axes $\left(\lambda_{1}=0.588\right.$ and 0.155 , $\lambda_{2}=0.065$ and 0.122 , respectively) accounted together for $65 \%$ of the total variance, respectively. Both ordinations were highly significant $(p<0.005)$ according to the Monte Carlo permutation test carried out on the first axis and on all four canonical axes together.

RDA clearly grouped the samples collected from Lake TREL according to the sampling dates and the position of each group is related to a precise combination of environmental variables, (compare with TWINSPAN ordination, Tab. 6). The seasonal variations in both phytoplankton and environmental variables can be followed by moving anti-clockwise from June 97 to June 98 in figure 4 (left panel). The interannual variability is suggested by the different locations of the samples collected in June 97 and 98.

RDA ordination for Lake SERO confirms that the seasonal variations in this lake are less obvious as shown by the location of all summer and autumn samples in the central part of the plot, corresponding to intermediate physico-chemical conditions. Only the samples collected in winter and early summer are clearly separate from the others, a response to the lower water temperature and higher nutrient concentrations respectively. A reduced interannual variability is highlighted by the proximal positions of all samples collected in June 97 and 98.

The length of the environmental vectors shows that water temperature and $\mathrm{pH}$ are both driving factors associated with the seasonal variations of the phytoplankton composition in both lakes. Alkalinity and $\mathrm{NO}_{3}-\mathrm{N}$ appear to be more important in Lake TREL than in SERO, where all nutrients appear to play a similar role.

Seasonal variations in diatom assemblages of the two lakes could be related to the summer evolution of phytoplankton. From July to October 1997 both lakes showed high abundances of some Brachysira species (Tab. 6), while all other frequent taxa were different in the two lakes. Early summer 1998 was characterized in both lakes by a higher abundance of Achnanthes cf. biasolettiana, but Lake TREL was also characterised by a particularly high biodiversity (Tolotti 2001, in press). A higher abundance of Achnanthes acidoclinata, an indicator of acid conditions (Lange-Bertalot \& Metzeltin 1996), was recorded in Lake SERO (Fig. 4 right panel) during1997.

\section{DISCUSSION}

The investigation on phytoplankton and littoral epilithic diatoms in the 16 lakes of the Adamello-Brenta Regional Park allowed their trophic classification to be improved. The classification of all lakes sampled in 1996 into the oligotrophic class, suggested by the low nutrient level (Tab. 2), was confirmed by chlorophyll concentrations, phytoplankton biovolume and by the abundance of oligotraphentic species in both algal communities. The lack of a complete correspondence between the trophic levels obtained considering phyto- 
plankton and littoral diatoms respectively (Tab. 2) may be partially due also to the different approaches adopted by the classification methods used in the present study. In fact, trophic classification based on phytoplankton is derived exclusively from the total algal biovolume, while the method based on littoral diatoms depends on species composition and relative abundances of each taxon.

The seasonal part of the study showed that a lengthy sampling period can improve the phytoplankton-based trophic classification allowing the differences in the trophic level of two lakes (which appeared very similar after the first single spot sample of 1996) to be highlighted. The diatom-based trophic classification (Hofmann 1994) of lakes TREL and SERO was not significantly improved by the extension of the seasonal part of the study (Tab. 2 and 3), probably as a result of the more pronounced temporal stability and slow growth of the benthonic algae compared with phytoplankton.

Differences in the trophic level of lakes TREL and SERO could not be comprehensively explained either by the morphological features or by the physico-chemical variables of the two lakes, suggesting that interactions between the different components of the biological community should be taken in consideration. The presence of stocked fishes in TREL could indirectly stimulate the phytoplankton growth rate through the increased nutrient regeneration (Vinerbrocke \& Leavitt 1999) and/or grazing pressure on the large zooplanktonic taxa (Mc Queen et al. 1986), as observed also in high mountain lakes (e.g. Nauwerck 1966; Cruz-Pizarro \& Carrillo 1991). This hypothesis seems to be supported by the results of zooplankton analyses carried out at the lakes of the Park, which highlighted that zooplankton taxa resistant to fish predation, like Cyclops abyssorum tatricus, are more abundant in Lake TREL than in Lake SERO (Angeli \& Cantonati, in prep.).

The general species composition of the algal communities recorded in the lakes of the Adamello-Brenta Regional Park is largely in accordance with that reported for oligotrophic high mountain or sub-arctic lakes of the Northern hemisphere. The majority of the identified diatom taxa are classified as "alpine" or "Nordic" species (Krammer \& Lange-Bertalot 19811996). Phytoplanktonic communities are composed of a reduced number of oligotraphenthic taxa also found in lowland lakes. The lower number of phytoplankton taxa recorded in higher lakes confirms the important role of altitude and related climatic conditions, particularly the duration of the winter ice cover, in the determination of the phytoplankton species composition of high mountain lakes (Nauwerck 1966, 1994). The temporal and vertical distribution of Dinophyceae and Cryptophyceae in the lakes studied is in accordance with their tolerance to low light intensity and to their partial mixotrophic capacity (Rhode et al. 1966).
Because of the wide geographical distribution of the majority of the phytoplankton taxa, the characterization of their nutrient and $\mathrm{pH}$ preference at species level is more difficult than for diatoms. Nevertheless, some species associations were found which are reported to be sensitive to acidification processes and some that may be used as indicators for oligotrophic conditions. In particular, the prevalence of Chrysophyceae and Dinophyceae, even in mid summer, is viewed as typical for high mountain lakes with low $\mathrm{pH}$ values (Willén et al. 1990). In a survey of a large group of high mountain lakes on acid rocks in Tyrol (Austria), Dinophyceae were dominant in lakes at $\mathrm{pH}$ lower than 6 , while Chrysophyceae were dominant mainly at $\mathrm{pH}$ ranging from 6 to about 7 (Pfister 1988). Among the Dinophyceae, the presence of some Peridinium species belonging to the section umbonatum, is considered important as some ecotypes of this group are seen as key indicators of acidified conditions in mountain lakes of North Europe (Rosén 1981; Willén et al. 1990; Nauwerck 1994) and North America (e.g. Schindler et al. 1985). In the lakes studied, these ecotypes (of the species $P$. inconspicuum and $P$. umbonatum) were particularly abundant either in the lakes or in the periods (early summer) characterized by low $\mathrm{pH}$ values and their presence was regularly associated with the acidophilous benthic diatoms Achnanthes acidoclinata and Eunotia exigua (Tabs 5-7). These two diatoms species, together with Eunotia subarcuatoides, have been recently reported in acidified mid altitude lakes and streams in Central Europe (Lange-Bertalot \& Metzeltin 1996). Low quantities of planktonic diatoms are characteristic of strongly oligotrophic lakes (Rosèn 1981) with $\mathrm{pH}$ lower than 7, as highlighted by many investigations on the acidification of high mountain lakes in Europe (e.g. Pfister 1988; Willén et al. 1990; Nauwerck 1994).

These general features of the phytoplankton and epilithic diatom assemblages are in accordance with the chemical composition of the lakes (Tolotti 2001, in press), confirming their general sensitivity to airborne pollution and episodic acidification events in late spring or early summer driven by ice-melt.

Examination of seasonal variations of phytoplankton and littoral diatoms in two selected lakes (TREL and SERO) confirmed the difference between two apparently similar lakes. Slightly differences in the physicochemical variables (Tab. 3) were accompanied by pronounced biological differences regarding both phytoplankton and benthic diatoms. The different species composition of the littoral diatom communities can be largely explained by differences in the mineralization level of the two lakes (Tolotti 2001, in press). Differences in phytoplankton species richness and composition are partially due to the smaller size and depth and to the shallower and more complex shores of TREL, which may promote the growth of several thicoplanktonic Zygnemataceae and Cyanophyceae. The develop- 
ment of small euplanktonic Zygnemataceae, as recorded in TREL in late summer and autumn 1997 have previously been observed in high mountain lakes (e.g. Pfister 1988), also during nutrient enrichment experiments (Witt 1978). With regard to TREL the phenomena could be due either to the slightly higher mineralization levels and nutrient concentrations in comparison to SERO (Tab. 3), or to positive effects on nutrient recycling operated by the stocked fish (Angeli \& Cantonati, in prep.). The dominance of several small flagellated algae belonging mainly to the group Chrysophyceae in Lake SERO reflects the oligotrophic conditions, in addition to the observation regarding the ecological advantage given by both small size and motility in poor high mountain lakes (Tilzer 1972). The "poorness" of lake SERO seems to be confirmed also by the less pronounced and less complex seasonal and interannual variations of phytoplankton composition and quantity (Tab. 7, Fig. 4 right panel).

Both phytoplankton and benthic diatom assemblages appear to be strongly affected by physico-chemical features of the lakes studied. However, the multivariate analyses highlighted that the two algal communities exhibit different responses to different environmental variables. The composition of the diatom community of the lakes sampled in 1996 (characterised by a large proportion of acidophilous species) appears to be affected mainly by $\mathrm{pH}$ and mineralization level and differentiates between low and extremely low-buffered lakes (Tolotti 2001 , in press). The importance of geochemical factors in determining diatom composition is reported for mountain lakes in several European regions (e.g. Stevenson et al. 1991; Marchetto \& Schmidt 1993; Niederhauser 1993) and represents the basis for use of benthic diatoms for monitoring of acidification processes due to diffuse human impact. Phytoplankton assemblages appear to be more clearly influenced by nutrients, in particular $\mathrm{TP}, \mathrm{NH}_{4}-\mathrm{N}$ and $\mathrm{NO}_{3}-\mathrm{N}$. The varying levels of importance of the nutrient concentrations in the two lakes studied during the seasonal survey, in particular the key role of phosphorus concentration in Lake SERO, could partially explain the differences in the phytoplankton communities and in the trophic level of the two lakes. pH exhibited a secondary role in determining variations in the species composition in lakes sampled in 1996, while showing a clearer relation to the seasonal development of phytoplankton in both lakes studied during 1997 and 1998 (Fig. 4).

\section{CONCLUSIONS}

The examination of phytoplankton and littoral epilithic diatoms in the high mountain lakes of the Adamello-Brenta Regional Park has improved the knowledge of algal biodiversity in this protected area, supplementing information from a recent investigation of springs and low order mountain streams in the Park (Cantonati 1998).
Results of the chemical analyses were validated by trophic classification of the lakes and by the identification of algal species assemblages considered as indicators of oligotrophy and acid sensitivity respectively.

The different responses of phytoplankton and littoral diatoms to physico-chemical conditions, highlighted by multivariate analyses and seasonal investigations, suggest that the study of the two algal communities may provide different contributions to the understanding of the effects of environmental changes on high mountain lakes. The importance of geochemical factors, such as $\mathrm{pH}$ and mineralization levels, as driving variables for the epilithic diatoms species composition allows an evaluation of the sensitivity of the lakes to airborne, diffuse pollution to be made. On the other hand, the key role of nutrients in determining phytoplankton assemblage and biomass variations allow researchers to follow the trophic evolution of lakes and to monitor the effects of nutrient enrichment due to pasture or tourist activities, which are among the commonest direct human impacts on high mountain environments (Catalan et al. 1993). The combination of the contributions provided by the study of the two algal communities thus facilitates a deeper and integrated understanding of the responses of the whole lake ecosystem to complex environmental (e.g. climate) changes.

\section{ACKNOWLEDGMENTS}

The author is very grateful to the Adamello-Brenta Regional Park for financial support towards this research, to Dr. M. Cantonati (MTSN) coordinator of the research, and to all collaborators from the Hydrobiological section of the MTSN, who participated at the field work and contributed to the different steps of the work. Part of the present research has been done in collaboration with the Working Group Hydrobotany, Institute of Botany, University Innsbruck. In particular the author wants to thank Prof. E. Rott and Dr. E. Pipp for editorial comments and help during numerical analyses. Thanks also to Dr. Martin Kernan (Environmental Change Research Centre, University College London) for the linguistic revision of the manuscript.

\section{REFERENCES}

Angeli, N. \& M. Cantonati. (2001). The zooplankton of two high mountain lakes affected by different anthropogenic impacts. in preparation.

Arzet, K. 1987. Diatomeen als pH-Indikatoren in subrezenten Sedimenten von Weichwasserseen. Ph.D. Thesis, University of Innsbruck. 24: 266 pp.

Baldi, E. 1932b. Note zoologiche sopra alcuni laghi della Presanella. II. Il Lago Serodoli. Mem. Mus. Stor. Nat. Ven. Trident., 1: 167-192.

Brettum, P. 1989. Alger som indikatorer på vannkvalitet i norske innsjøer. Planteplankton. NIVA Report: $111 \mathrm{pp}$.

Cantonati, M. 1998. Diatom communities of springs in the Southern Alps. Diatom Research, 13(2): 201-220.

Catalan, J, E. Ballesteros, G. Esperança, A. Palau \& L. Camarero. 1993. Chemical composition of disturbed and 
undisturbed high mountain lakes in the Pyrenees: a reference site for acidified lakes. Wat. Res., 27: 133-141.

Cruz-Pizarro L. \& P. Carrillo. 1991. Top-down regulation under different species-specific and size-structure grazer assemblages in an oligotrophic lake. Mem. Ist. ital. Idrobiol., 48: 23-27.

Ettl, H. 1978. Xanthophyceae Teil 1. In: Ettl, H., J. Gerloff, H. Heyning \& D. Mollenhauer (Eds), Süsswasserflora von Mitteleuropa. G. Fischer, Jena, Stuttgart: 530 pp.

Giussani, G., R. de Bernardi, R. Mosello, I. Origgi \& T. Ruffoni. 1986. Indagine limnologica sui laghi alpini d'alta quota. Documenta Ist. ital. Idrobiol., 9: 1-415.

Halac, S., M. Felipe, L. Camarero, S. Sommaruga-Wögrath, R. Psennre, R. Catalan \& R. Sommaruga. 1997. An in situ enclosure experiment to test the solar UV-B impact on plankton in a high altitude lake. 1) lack of effect on phytoplankton composition and growth. J. Plankton Res., 19: 1671-1687.

Heinonen, P. 1980. Quantity and composition of phytoplankton in Finnish inland waters. Publ. Water Res. Inst. 37, Vesihallitus-National Board of Waters, Finland.

Hill, M.O., R.G.H. Bunce \& M.W. Shaw. 1975. Indicator species analysis, a divisive polythetic method of classification and its application to a survey of native pinewood in Scotland. J. Ecol., 63: 597-613.

Hofmann, G. 1994. Aufwuchs-Diatomeen in Seen und ihre Eignung als Indikatoren der Trophie. Bibl. Diatomol., 30, J. Cramer, Berlin Stuttgart: $241 \mathrm{pp}$.

I.R.S.A.-C.N.R. 1994. Metodi analitici per le acque. Quaderni Istituto di Ricerca sulle Acque, Roma.

Krammer, K. \& H. Lange-Bertalot. 1981-1996. Bacillariophyceae. In: Ettl, H., J. Gerloff, H. Heyning \& D. Mollenhauer (Eds), Süsswasserflora von Mitteleuropa. G. Fischer Verlag, Stuttgart, New York.

Lange-Bertalot, H. \& A. Steindorf. 1996. Rote Liste der limnischen Kieselalgen (Bacillariophyceae) Deutschlands. Schriften-Reihen für Vegetationskunde, 28: 633-677.

Lange-Bertalot, H. \& D. Metzeltin. 1996. Indicators of Oligotrophy. In: H. Lange-Bertalot (Ed.), Iconographia Diatomologica 2. Koeltz, Koenigsstein: 390 pp. .

Lorenzen, C.J. 1967. Determination of chlorophyll and phaeopigments: spectrophotometric equations. Limnol. Oceanogr., 12: 543-556.

Lund, J.W.G., G. Kipling \& E.D. LeCren. 1958. The inverted microscope method for estimating algae number and statistical basis of estimating by counting. Hydrobiologia, 11 : 143-170.

Marchetto, A. \& R. Schmidt. 1993. A regional calibration data set to infer lake water $\mathrm{pH}$ from sediment diatom assemblages in alpine lakes. Mem. Ist. ital. Idrobiol., 51: 115125.

Marker, A.F, Nusch, E.A., Rai. H. \& B. Riemann. 1980. The measurement of photosynthetic pigments in freshwaters and standardization of methods: conclusion and recommendation. Arch. Hydrobiol. Beih. Ergebn. Limnol., 14 91-106.

Mc Queen, D.J., R.J. Post \& E.L. Mills. 1986. Trophic relationships in freshwater pelagic ecosystems. Can. J. Fish. aquat. Sci., 43: 1571-1581.

Nauwerck, A. 1966. Beobachtungen über das Phytoplankton klarer Hochgebirgsseen. Schweiz. Zeit. Hydrol., 28: 4-28.

Nauwerck, A. 1994. A survey on water chemistry and plankton in high mountain lakes in northern Swedish Lapland. Hydrobiolgia, 274: 91-100.

Niederhauser, P. 1993. Diatomeen als Bioindikatoren zur Beurteilung der Belastung elektrolytarmer Hochgebirgsseen durch Säuren und Nährstoffe. Ph.D. Thesis, University Zürich: 109 pp.

Pechlaner, R. 1971. Factors that control the production rate biomass of phytoplankton in high mountain lakes. Mitt. Internat. Verein. Limnol., 19: 125-145.
Pfister, P. 1988. III Phytoplankton in Tiroler Hochgebirgsseen. In: R. Psenner (Ed.), Versauerung von Hochgebirgsseen in kristallinen Einzusgebieten Tirols und Kärnterns. Bundesministerium für Land - und Fortwirtschaft, Wien, 335 pp.

Psenner, R. \& J. Catalan. 1994. Chemical composition of lakes in crystalline basins: a combination of atmospheric deposition, geologic background, biological activity and human action. In: R. Margalef (Ed.), Limnology Now: A paradigm of planetary problems. Elsevier Science, Amsterdam, 255-314.

Pugnetti, A. \& R. Bettinetti. 1995. The phytoplankton communities of two acid sensitive alpine lakes (Lakes Paione, Central Alps, Italy). Mem. Ist. ital. Idrobiol., 53: 39-52.

Rhode, W. 1955. Can plankton production proceed during winter darkness in subarctic lakes? Proc. Int. Ass. theor. appl. Limnol., 12: 117-122.

Rhode, W., J.E. Hobbie \& R.T. Wright. 1966. Phototrophy and heterotrophy in high mountain lakes. Verh. int. Ver. Limnol., 16: 302-313.

Rosén, G. 1981. Phytoplankton indicators and their relations to certain chemical and physical factors. Limnologica, 13(2), 263-290.

Rott, E. 1981. Some results from phytoplankton counting intercalibrations. Schweiz. Z. Hydrol., 43(1): 34-62.

Rott, E. 1984. Phytoplankton as biological parameter for the trophic characterization of lakes. Verh. int. Ver. Limnol., 22: 1078-1085.

Rott, E. 1988. Some aspects of the seasonal distribution of flagellates in mountain lakes. Hydrobiologia, 161: 159170.

Rott, E. \& L. Pernegger. 1994. Epilithic cyanophytes from soft-water mountain lakes in the Central Alps (Austria) and in the Pirin Mountain (Bulgaria) with special reference to taxonomy and vertical zonation. Algol. Studies, 75: 249-264.

Salamso, N. \& F. Decet. 1997. Seasonal and interannual changes in the chemical characteristics and phytoplankton in a mountain lake in the Eastern Italian Alps (Lake Calaita, Trentino). Int. Revue ges. Hydrobiol., 82: 15-31.

Schiefele, S. \& F. Kohmann. 1993. Bioindikation der Trophie in Fliessgewässern. Umweltforschungsplan der Bundesministeriums für Umwelt, Naturschutz und Reaktorsicherheit, Forschungsbericht Nr. 10201 504, Deutschaland: 272 pp.

Schindler, D.W., K.H. Mills, D.F. Malley, D.L. Findlay, J.A. Shearer, I.J. Davies, M.A. Turner, G.A. Linsey \& D.R. Cruikshank. 1981. Long-term ecosystem stress: the effect of years of experimental acidification on a small lake. Science, 228: 1395-1401.

Schmidt, R. \& R. Psenner. 1992. Climate changes and anthropogenic impacts as causes for $\mathrm{pH}$ fluctuation in remote alpine lakes. Documenta Ist. ital. Idrobiol., 32: 31-57.

Schneider, U. 1981. Phytoplankton und Primärproduktion in einigen Hochgebirgsseen des Kantons Tessin. Ph.D. Thesis, University Bern: 152 pp.

Shannon, C.E. \& W. Weaver. 1949. The mathematical theory of communication. University of Illinois Press, Urbana: $117 \mathrm{pp}$.

Stella, E. 1931. Intorno ad alcuni laghi alpini del Trentino, dell'Ampezzano e dell'Alto Adige. Mem. Mus. St. nat. Ven. Trident., 1: 45-66.

Stevenson, A.C., S. Juggins, H.B. Birks, D.S. Anderson, N.J. Anderson, R.W. Battarbee, F. Berge, R.B. Davis, R.J. Flower, E.Y. Haworth, V.J Jones, J.C. Kingston, A.M. Keiser, M.A.R. Munro \& I. Renberg. 1991. The surface Water Acidification Project Paleolimnology Programme: Modern Diatom/Lake-Water Chemistry Data-Set. Ensis Publishing, London: 86 pp.

Ter Braak, C. 1988. CANOCO - A FORTRAN program for canonical community ordination by [partial] [detrended] 
[canonical] correspondence analysis, principal components analysis and redundancy analysis. Manuscript, Agricultural Mathematics Group, Wageningen, the Netherlands: $95 \mathrm{pp}$.

Thies, H., U. Nickus, C. Arnold, R. Schnegg, A. Wille \& R. Psenner. 2000. Biogeochemistry of a high mountain lake in the Austrian Alps. Verh. int. Ver. Limnol., 27: 517-520.

Tilzer, M. 1972. Dynamik und Produktivität von Phytoplankton und pelagischen Bakterien in einem Hochgebirgssee (Vorderer Finstertaler See, Österreich). Arch. Hydrobiol., 3: 201-273.

Tolotti, M. (2001). Littoral diatom communities in high mountain lakes of the Adamello-Brenta Regional Park (Trentino, Italy) and their relation to acidification. In: Jahn, R., J.P. Kociolek, A. Witkowski \& P. Compère (Eds), Lange-Bertalot-Festschrift.. Gantner, Ruggel: (in press).

Tolotti, M. \& M. Cantonati. 2000. Temporal and vertical variations of chlorophyll concentrations in high mountain lakes of the Adamello-Brenta Regional Park (Trentino, Italy). Verh. int. Ver. Limnol., 27: 521-526.

Tomasi, G. 1962. Origine, distribuzione, catasto e bibliografia dei laghi del Trentino. Stud. Trent. Sc. Nat., 1-2: 1-33.

Tonolli, V. 1947. Gli alti laghi della Val Bognaco. Parte I. Mem. Ist. ital. Idrobiol., 3: 187-269.

Received: March 2001

Accepted: October 2001
Tonolli V. \& L. Tonolli. 1951. Osservazioni sulla biologia ed ecologia di 170 popolamenti zooplanctonici di laghi italiani di alta quota. Mem. Ist. ital. Idrobiol., 6: 53-136.

Utermöhl, H. 1958. Zur Vervollkommung der quantitative Phytoplankton-Methodik. Mitt. Internat. Verein. Limnol., 9: 1-38.

Vinerbrooke, R.D. \& P.R. Leavitt. 1999. Phytobenthos and phytoplankton as potential indicators of climate change in mountain lakes and ponds: a HPLC-based pigment approach. J. N. Am. Benthol. Soc., 18(1): 15-33.

Vollenweider, R.A. 1968. Die wissenschaftlichen Grundlagen der Seen- und Fließgewässer-eutrophierung unter besonderer Berücksichtigung des Phosphors und des Stickstoffs als Eutrophierungsfaktoren. OECD, DAS/CSI/68.27.

Vollenweider, R.A. \& J. Kerekes. 1982. Eutrophication of Waters, Monitoring, Assessment and Control. OECD, Paris: $154 \mathrm{pp}$.

Willén, E., S. Hajdu \& Y. Pejler. 1990. Summer phytoplankton in 73 nutrient-poor Swedish lakes - classification, ordination and choice of long-term monitoring objects. Limnologica, 20: 217-227.

Witt, U. 1977. Auswirkungen der künstlichen Düngung eines Hochgebirgssees (Vorderer Finstertaler See, Kühtai, Tirol). Arch. Hydrobiol., 81: 211-232.

Zucchelli, M. 1952. Osservazioni morfologiche e fisiche su alcuni laghi del Gruppo Adamello-Presanella. St. Trent. Sc. Nat., 29: 142-170. 